\title{
Manual RC Box Culvert Analysis and Designing
}

\author{
Applied Science
}

Ayaanle Maxamed Ali

Department: Civil Engineering

Program: Culvert Project 


\begin{abstract}
:
The culvert is small structures that are required for the under roads and its uses for the crossing of water like streams under the roads. The culvert structure balances the water flow on both sides of the roads, also is protecting and balance of the embankment to reduce the water flow level. There are different types of culverts shapes, and they are circle, arch, Slap \& box; therefore, these can be constructed by using different materials like; stones, bricks, reinforced cement concrete. Since the culvert crossing under the earthen embankment, so the culvert is subjecting a traffic load similarly as the roads carry; therefore, they required to be designed for such loads the acting on the surface of the culvert. This project is dealing with the RCC box culvert with and without cushions. The cushion depends on the road profile at the culvert location.
\end{abstract}




\section{INTRODUCTION}

The culverts are small structures or bridges which are used for the crossing channels under the crossing of the railways, roads, and flyover, also is used where the bearing capacity of the soil is low. The culvert is always more economical than the bridges because culvert is found where the discharge in the opening size is $18 \mathrm{~m} 2$; also, it depends on the number of cells where the roads generally cross high embankment. Generally, culvers are cast in situ, but it depends on the country you are because some countries they preferred due to economic and low cost with having fast workmanship. There are different types of culvert; it depends on its shape; also, it uses as a small bridge. Culvert spans generally are $6 \mathrm{~m}-10 \mathrm{~m}$ length so it can control all the water coming from the canals, river, and all the stormwater and floodwater to pass under the road safely. Rcc box culvert has four sides that monolithically connected. Some box culverts have three sides because there's raft or mat foundation in the bottom and two vertical wells in the sides. The cushioning is very important in every culvert, which decided to put under the road profile also the bearing capacity of that site soil available.

\section{PURPOSE}

The purpose of constructing the culvert is to convey surface water across. And there are other purposes like culverts support the embankment and the roadway for conveyance the traffic, culverts control the flooding hazards to the extent possible.

\section{CULVERTS}

Culvert is a small structure of a cross-drainage having a total length between $(6 \mathrm{~m}-10 \mathrm{~m})$ or smaller than. There are different types of culvert, and they are,

Pipe Culvert.

Box Culvert.

Rcc Solid Slap Culvert.

Pipe Arch Culvert.

Arch Culvert.

\section{PIPE CULVERT}

Pipe culvert may be a single or multiple pipes; therefore, if it's used a single culvert, then a large diameter culvert is required if the width of the water channel becomes greater than multiple pipe culvert is going to use in that place. The multiple pipe culvert is suitable to use for a large water channel. The diameter size of the pipe culverts is between $(1 \mathrm{~m} \mathrm{t} 06 \mathrm{~m})$. Pipe culverts are generally widely using, and they look like a rounded in shape. 
ISSN No:-2456-2165

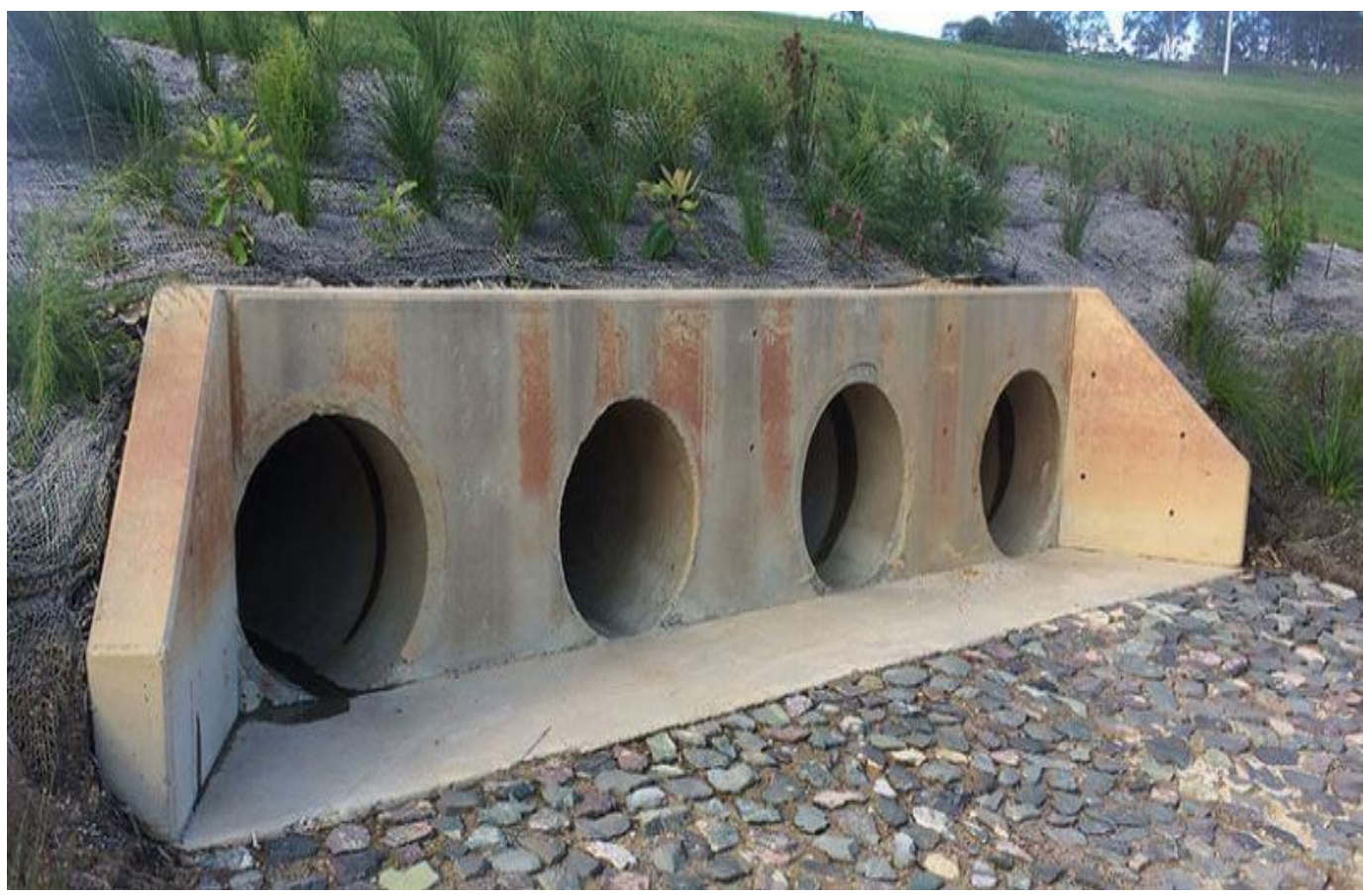

Fig 1:- Pipe Culvert

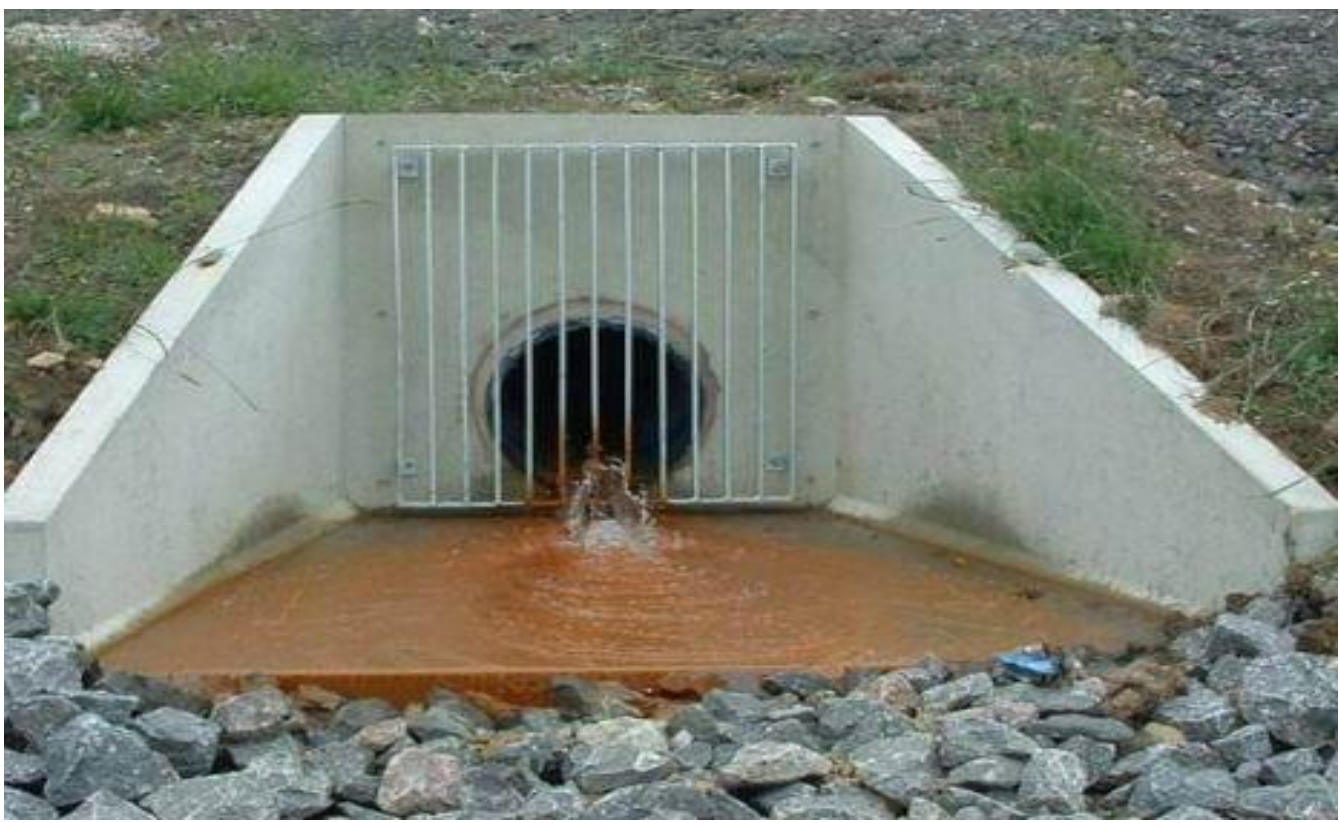

Fig 2:- Pipe Culvert with a filter 


\section{BOX CULVERT}

Box culvert is always in a rectangular shape, and the type of materials that used to make the box culvert are (cement, sand, reinforced, gravel). This type of culvert is used to drain the rainwater, river water, and stormwater under the road embankment. Also, box culvert is useful in the dry period because they can help the animals as a passage cross of the railroad or highways.

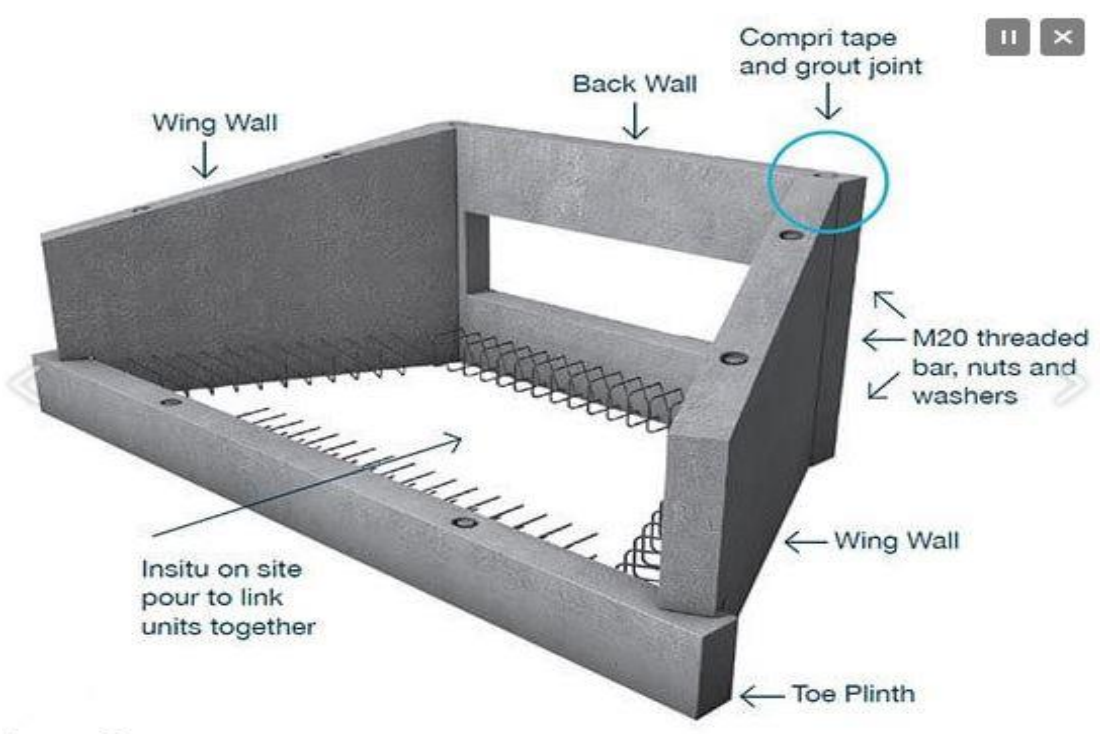

Fig 3: - Front of the Box Culvert

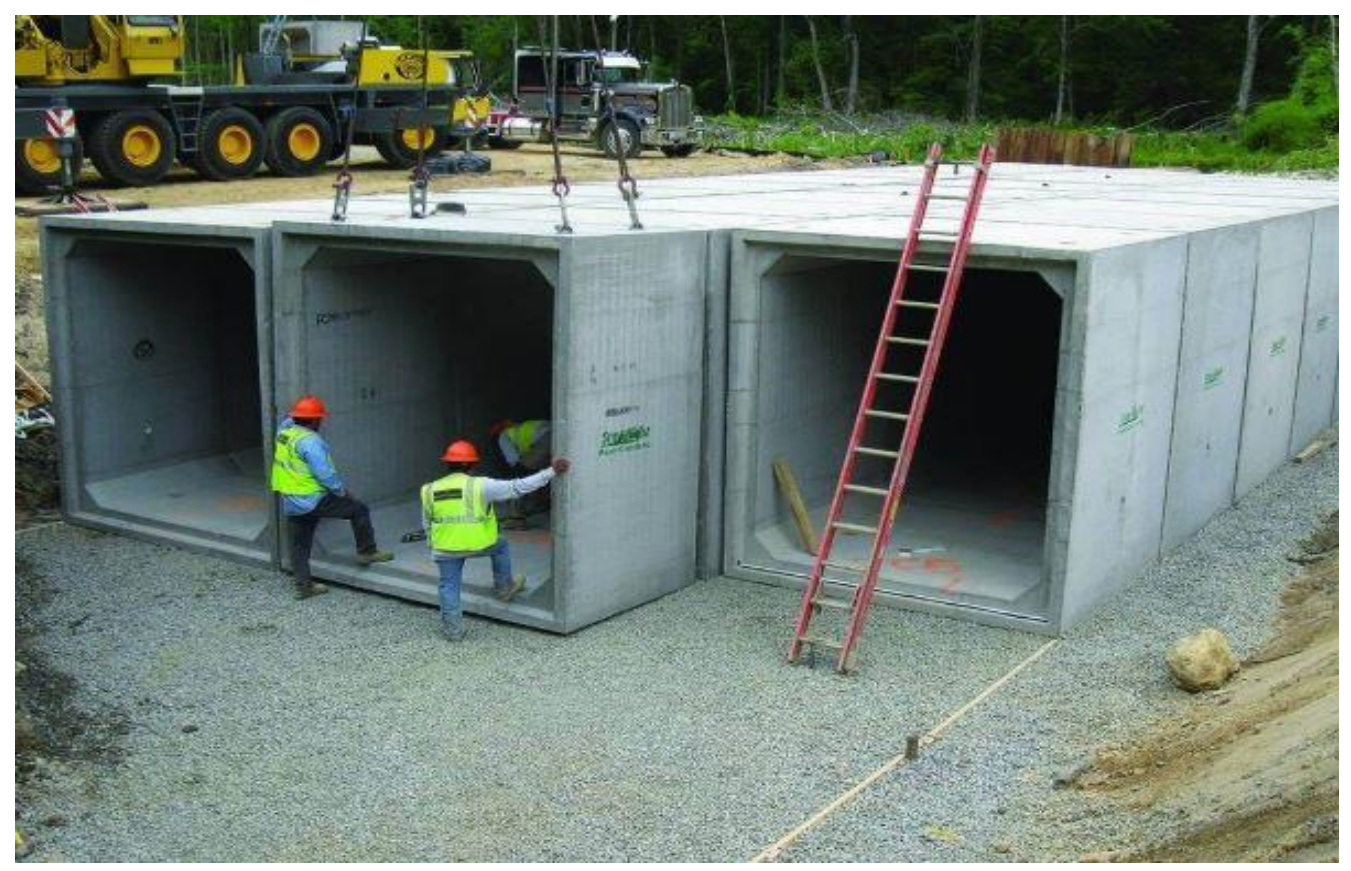

Fig 4:- Box Culvert 


\section{PIPE ARCH CULVERT}

Pipe Arch Culvert means that they look like a half-circle and half arch culvert. This type of culverts they are suitable for the places of the large water flow, but the flow capacity should be stable. Pipe arch culverts they are good for the sewages and fishes because they can use drainage easily without stocking the flow at the bottom. These types of the culvert are very useful so you can see in many places;also, these culverts have a very beautiful appearance.

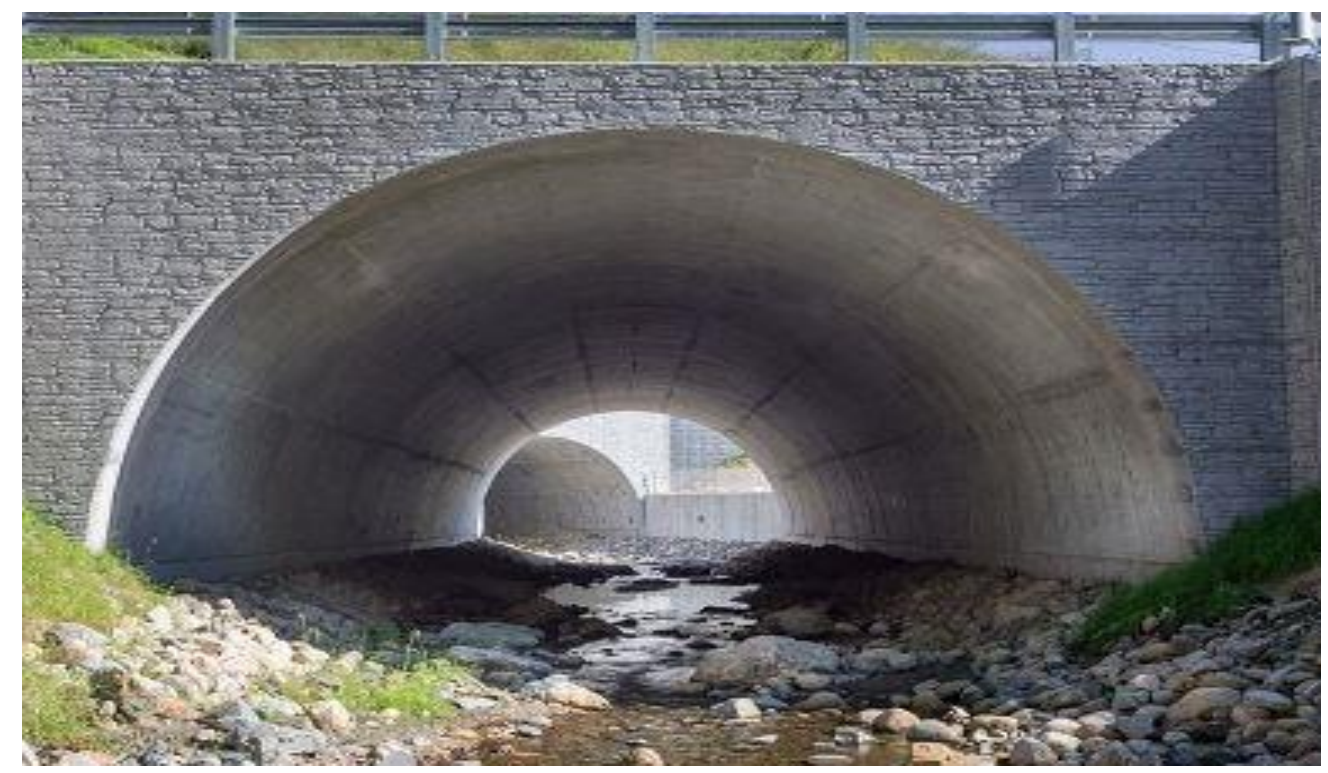

Fig 5:- Pipe Arch Culverts

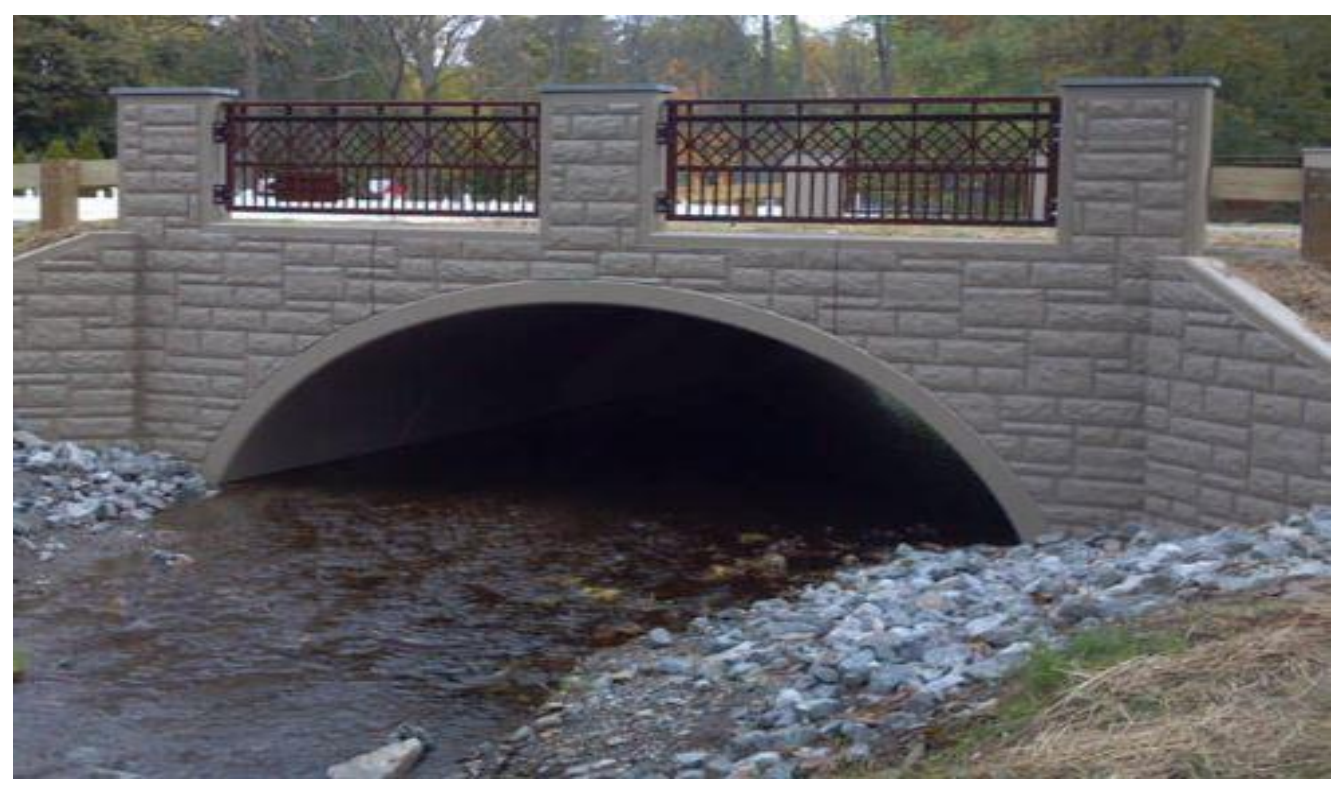

Fig 6:- Pipe arch Culvert with a small channel 


\section{RCC SOLID SLAP CULVERT.}

Solid slap culverts are provided where the big canals and the rivers also are used as a small bridge in road vehicles. In these types of culverts, the foundations are laid under the ground surface. A series of box culver is laid in the ground then pavement is put on the top surface.

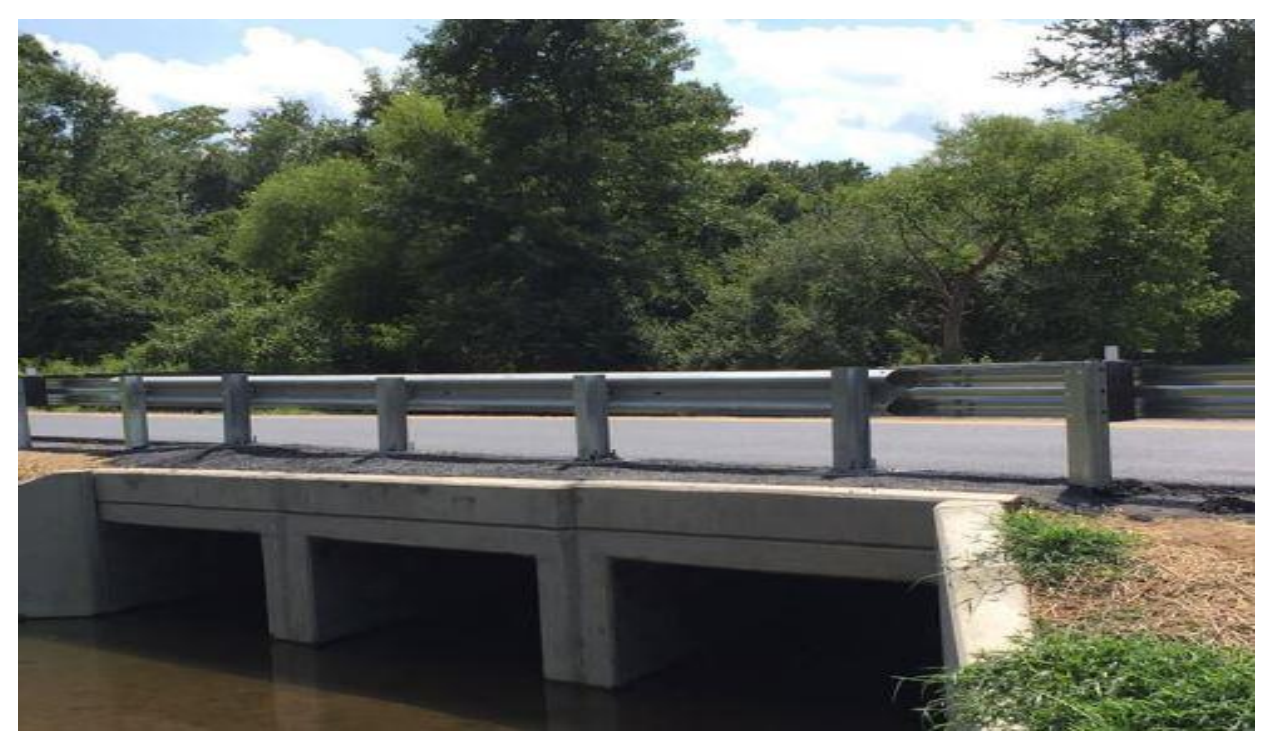

Fig 7: Rcc Solid Slap Culvert

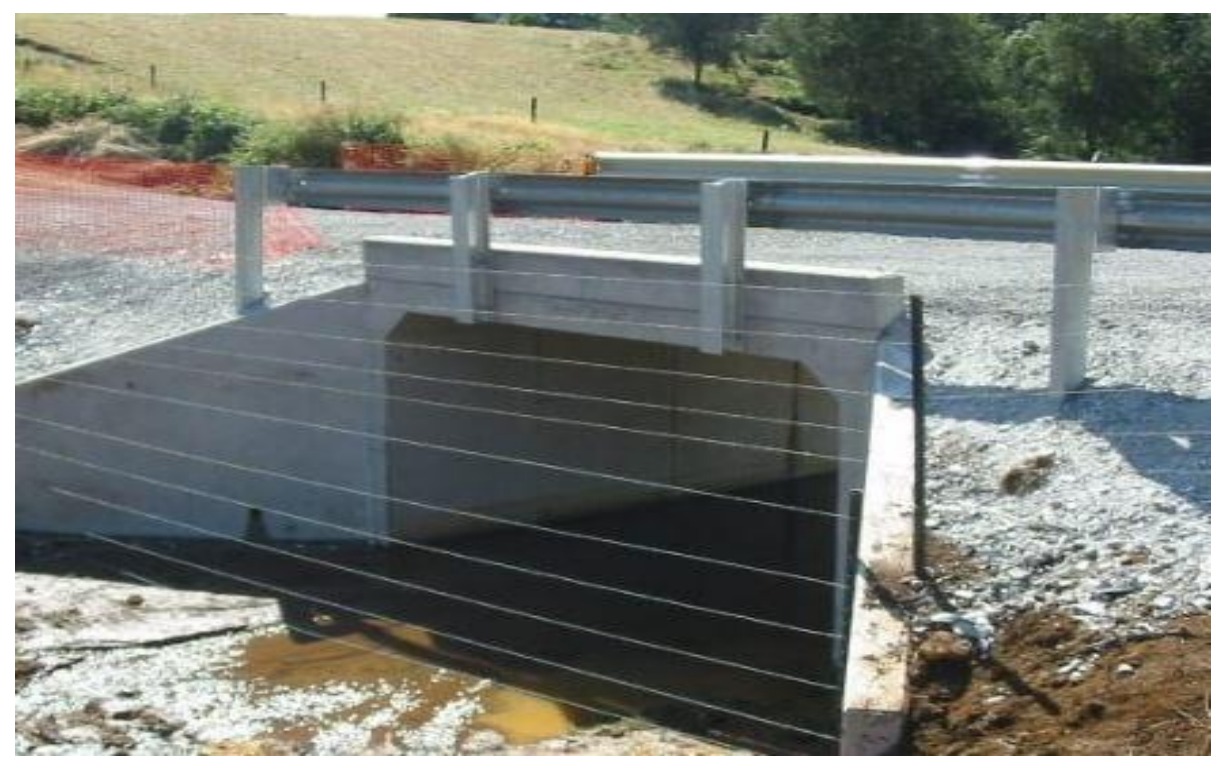

Fig 8: Rcc Solid Slap Culvert with a filter 


\section{ARCH CULVERT}

These types of the culvert are similar to pipe arch culvert, but in this culvert, there's mat provided below the arch. The passage of this culvert is very wide and can transmit a large flow of water. The material made of this culvert is sometimes concrete or some time is steel, so it depends on the design submitted of this culvert.

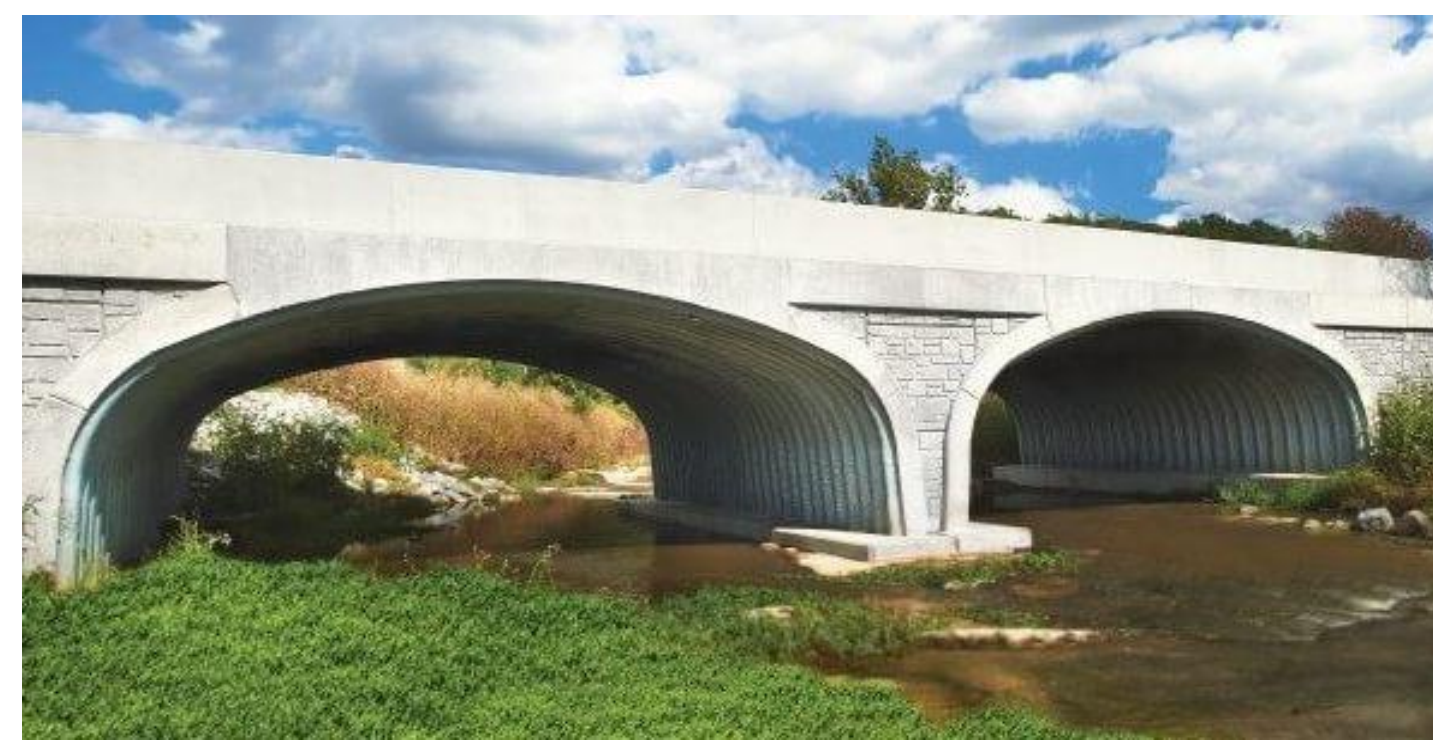

Fig 9: RCC Arch Culvert

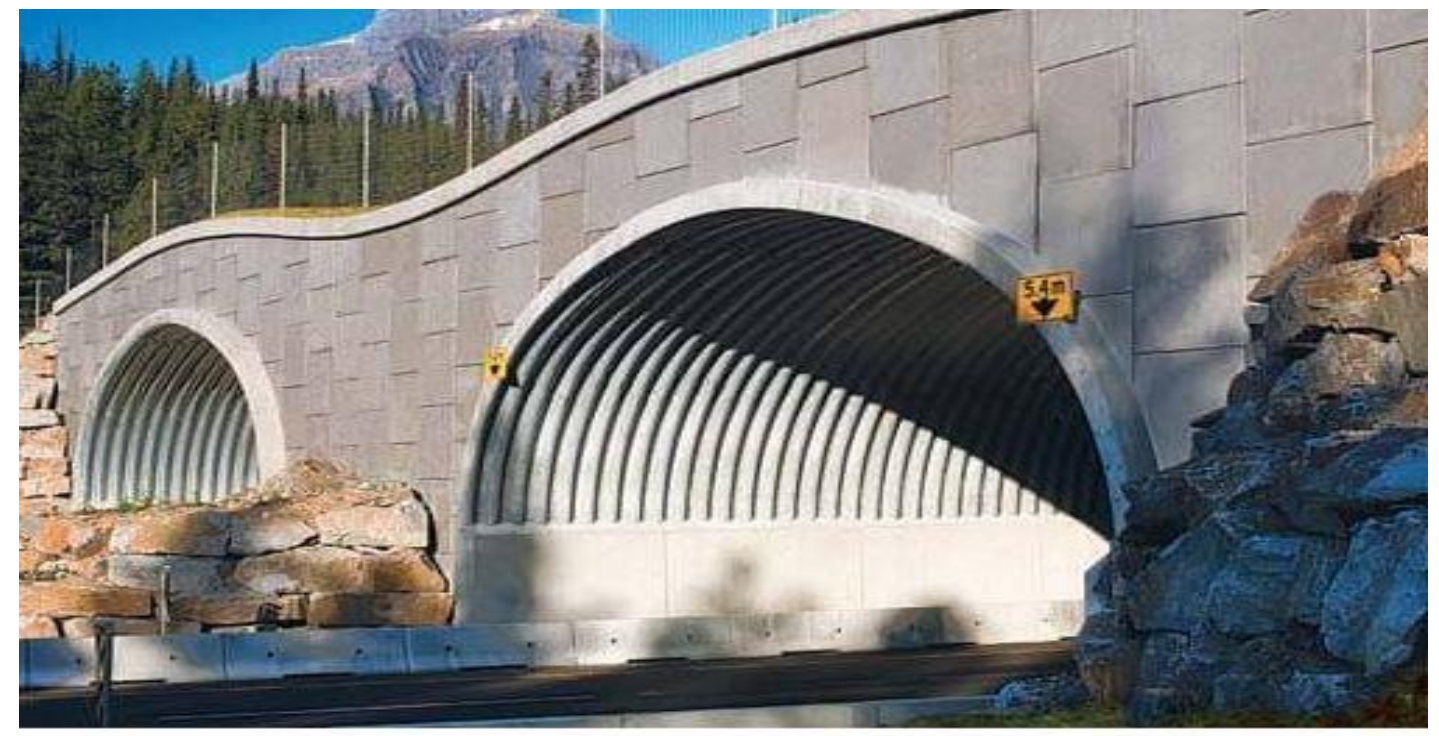

Fig 10: Steel Arch Culvert 


\section{THE MATERIAL OF CULVERT CONSTRUCTION}

Culvert is similar to pipes, but they are large in size. The type of material made the culverts are:

- Concrete

- Steel

- Plastic

- Aluminum

- High-density polyethylene

The most material preferred is concrete culverts. Concrete culverts contain cement, reinforcement, sand, and aggregate.

\section{CULVERT LOCATION}

Location of the culverts should be based on the usage and the economy. Generally, the provision of the culverts is recommended under the railway and roadway culverts are always economical. Culvers should be perpendicular to the roadway. Culverts must be greater size diameter to allow maximum water level pass it through.

The Advantage of the Culverts;

- They prevent erosion.

- They prevent flooding.

- Allow water to flow under the roads.

- They divert water for farming and etc.

\section{CULVERT INSTALLATION AND SELECTION TIPS}

The following steps are considered for the construction of the culvert structure:

- Culverts should be built at the right elevation to reduce erosion.

- Cost maintenance should be considered during the selection of the type of culvert.

- Mitered at the edges of the culvert should carefully designed because they facilitate the inlet flow and outlet flow.

- The right aggregate should be used to the culvert because good aggregate is used to backfill on the top, underneath and sides of the culvert can make the culvert strong.

- Also, it should be considering the traffic and its capacity of that area because the different types of traffic have a different load on the ground, so it should be carefully designed.

- The material and the cost of construction must be available before the selection type of culverts.

\section{OTHER IMPORTANT CONSIDERATIONS FOR INSTALLATION OF CULVERT}

After you decided the type of culvert, you want to use, then be sure to confirm that all the environmental permits are updated. Also, check all the requirements of NPDES are meet, and the right material is available to build the culvert. 


\section{HYDRAULIC DESIGN OF CULVERT INFORMATION}

The performance of culvert design consists the transporting a flow from a side to the other side of the road. During the design, it's important to analyze the flow frequency then estimate the discharge frequency to set the allowable headwater elevation. The selection of the type of culvert depends on the discharge flow intensity, the allowable outlet velocity, and the controlling headwater design.

- The Requirement of The Culvert Design: -

- Impacts of the culvert size, the size on upstream, and the downstream flow.

- How will culvert fit into the appropriate drainageway master plan.

- The alignment, site information, and the length size of the culvert.

- Outlet velocity, and the headwater.

- Pipe material.

- Geotechnical data of that area.

\section{DISCHARGE}

The discharge that culvert transport from the other edge is always estimated of a preselected the recurrence storms; then culvert is designed to stand with a bigger limit than the present discharge rate.

\section{HEADWATER}

The culverts are designed the water flow of that area, so the elevation of that water is called headwater, and the stream depth measured from the culvert inlet is called headwater depth. Selecting streamelevation or headwater, it should be considered the following:

- The expected risk of the upstream and the downstream.

- The vertical loads that are coming from the traffic.

- Traffic interruption.

- Roadway elevation.

- The water-elevation inside the culvert.

\section{TAIL-WATER}

This water is the downstream channel depth flow measured from the invert in the culvert outlet. Tailwater can be an important factor in the culvert for hydraulic design during submerged outlets can cause the water in the culvert to flow full rather than moderately. Site inspection should be made in the downstream channel to determine if there are obstructions that will affect the tailwater flow depth.

\section{THE VELOCITY OF THE OUTLET}

The outlet velocity of the culvert is the water flow velocity measured at the downstream at the end of the culvert and its always higher velocity than the natural stream. This velocity causes a streambed to scour and erosion for the areas around the outlet culvert. The allowable velocity of the Outlet it depends upon the streambed type. If the velocity of flow in the Outlet is very high, it can reduce the barrel roughness. To increase the outlet suitability and to reduce the flow velocity, it's necessary to use some protection mechanisms or energy dissipation devices. The shape of the culvert and the size have a significant effect on the velocity of the outlet flow. Slope and the roughness of the culvert also have an effecting the outlet velocity. 


\section{ANALYSIS AND DESIGN OF RCC BOX CULVERT}

Analysis and Design

- The structural design of the RC box culvert includes the analysis of the rigid model frame for axialforces, shear-forces, and moments, due to the different types of loading: -

- Permanent Loads:

Dead Loads, superimposed dead-loads, the Horizontal earth pressure, Buoyancy, and hydrostatic pressure, settlement effect.

- Vertical Live Loads:

(HA or HB) Loads on the carriageway (Load model-1 Eurocode)

(Footway, track loads,cycle)

Accidental wheel loading.

Construction of traffic.

\section{- Horizontal Live Loads}

Live load Surcharge.

Traction.

Temperature effect.

Parapet Collision.

The accidental skidding.

The centrifugal loads.

Table 1: Divisions of the carriageway

\begin{tabular}{|c|c|c|c|}
\hline $\begin{array}{c}\text { Road Carriage } \\
\text { Width }(\mathbf{W})\end{array}$ & $\begin{array}{c}\text { Number of } \\
\text { National Lane } \\
(\mathbf{n})\end{array}$ & $\begin{array}{c}\text { Width of } \\
\text { national Lane }\end{array}$ & $\begin{array}{c}\text { Width of the } \\
\text { Remaining } \\
\text { Area }\end{array}$ \\
\hline $\mathrm{W}<5.4 \mathrm{~m}$ & 1 & $3 \mathrm{~m}$ & $\mathrm{~W}-3 \mathrm{~m}$ \\
\hline $5.4 \leq \mathrm{w}<6 \mathrm{~m}$ & 2 & $0.5 \mathrm{w}$ & 0 \\
\hline $6 \mathrm{~m} \leq \mathrm{w}$ & $\mathrm{Int}(\mathrm{w} / 3)$ & $3 \mathrm{~m}$ & $\mathrm{~W}-(3 * \mathrm{n})$ \\
\hline
\end{tabular}

Loads That acting on the Box Culvert (Eurocode 1 Part 2 (EN 1991-2) 


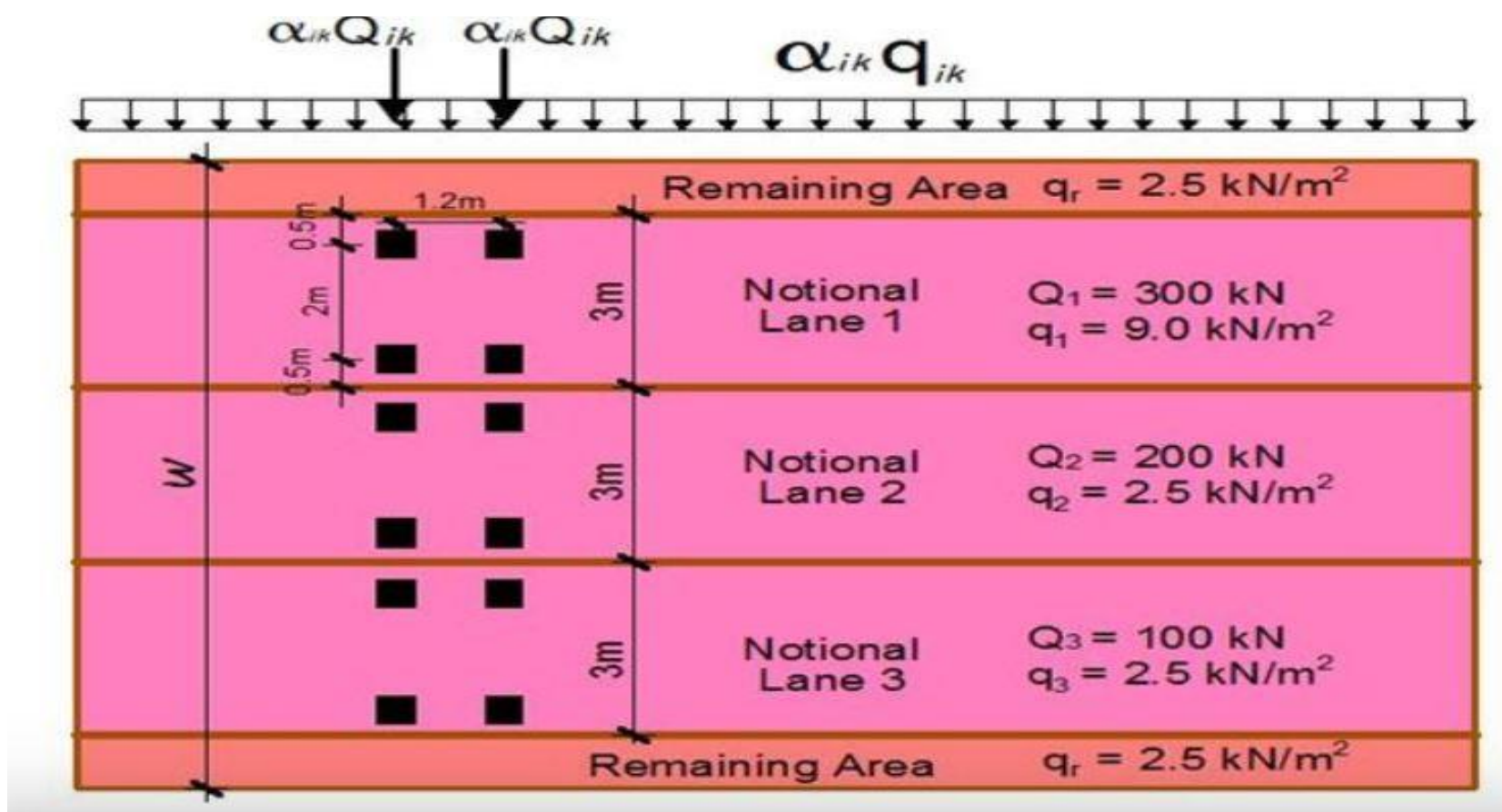

Fig 11: Steel Arch Culvert

\section{CONCENTRATED LOADS}

According to BD 31/ 01, the dispersal loads not necessary if the fill is lower than $600 \mathrm{~mm}$ thick for HA loading. But if the fill is thicker than $600 \mathrm{~mm}, 30$ units of the HB loads would be used by adequate dispersal loads by the fill.

\section{THE EARTH PRESSURE:}

Depending on the site condition, at rest pressure coefficient $K_{0}=1$-sin $\emptyset$ This formula is usually used for the Earth's pressure.

\section{\# Example:}

A concrete culvert has a parameter given below.

1- The top slap of the culvert is in direct contact with the carriageway and overlaid with $75 \mathrm{~mm}$ thick of asphalt.

2- At the top of the slap, there is a $1.2 \mathrm{~m}$ thick fill on the top culvert before the carriageway formation.

\section{* Geometry plan of the culvert}

- The total length of the culvert is $8 \mathrm{~m}$.

- The width of the culvert $\mathrm{C} / \mathrm{C}$ of the side walls is $2.5 \mathrm{~m}$.

- The height of the culvert $\mathrm{C} / \mathrm{C}$ of the top and bottom slap is a $2 \mathrm{~m}$.

- The length of the wing walls is $2.12 \mathrm{~m}$.

- The thickness of all elements is $300 \mathrm{~mm}$.

- The thickness of the asphalt layer is $75 \mathrm{~mm}$.

* Material Property of the culvert

- The angle of internal friction fill soil is $30^{\circ}$.

- The unit weight of the water is $9,8 \mathrm{KN} / \mathrm{M}^{3}$.

- The unit weight of backfill soil is a $19 \mathrm{KN} / \mathrm{M}^{3}$.

- The unit weight of the concrete is $25 \mathrm{KN} / \mathrm{M}^{3}$.

- The unit weight of the asphalt is a $22.5 \mathrm{KN} / \mathrm{M}^{3}$. 
- $\mathrm{F}_{\mathrm{ck}}=30 \mathrm{Mpa}$.

- $\mathrm{Fyk}=500 \mathrm{Mpa}$.

- The concrete cover is $50 \mathrm{~mm}$.

\section{Load Analysis}

- The width of the carriageway is $8 \mathrm{~m}$.

- The number of lanes is $8 / 3=2$ lanes.

- Width of the remaining area $=8-(2 * 3)=2 \mathrm{~m}$.

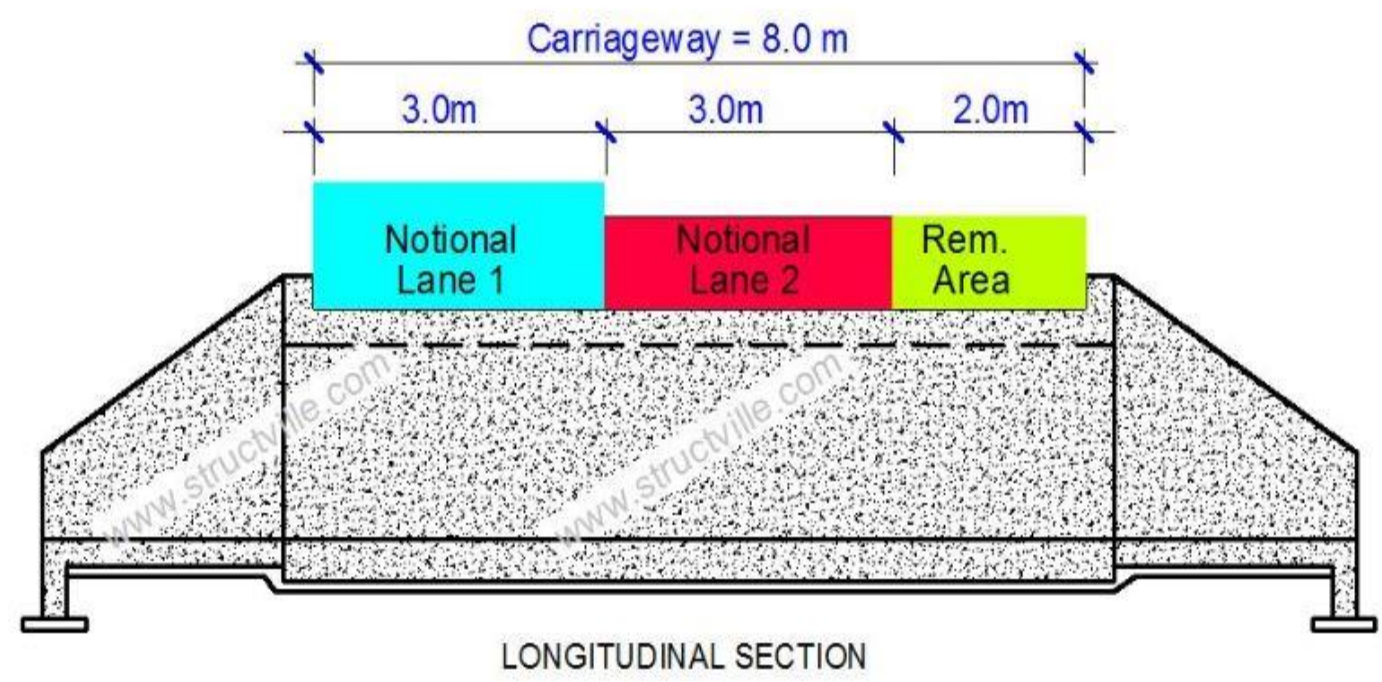

Fig 12: Carriage way

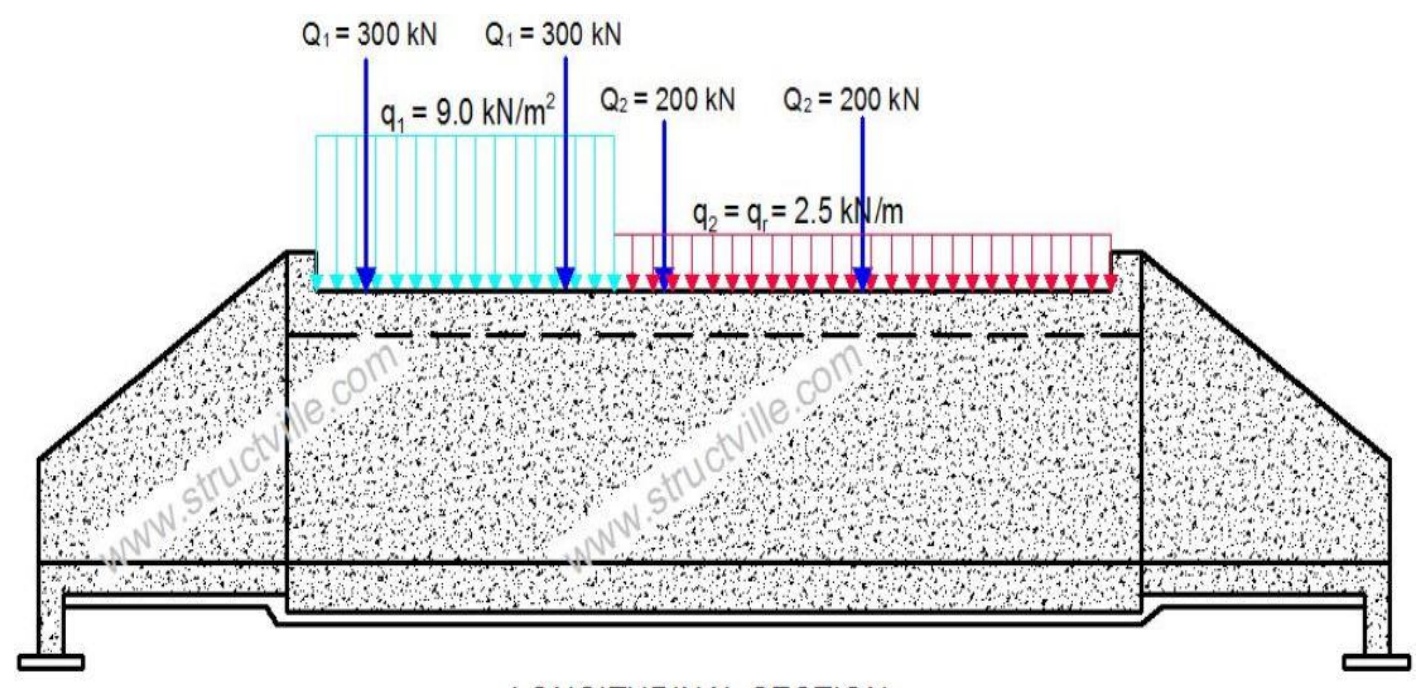

LONGITUDINAL SECTION

Fig 13: loads on the national lanes 


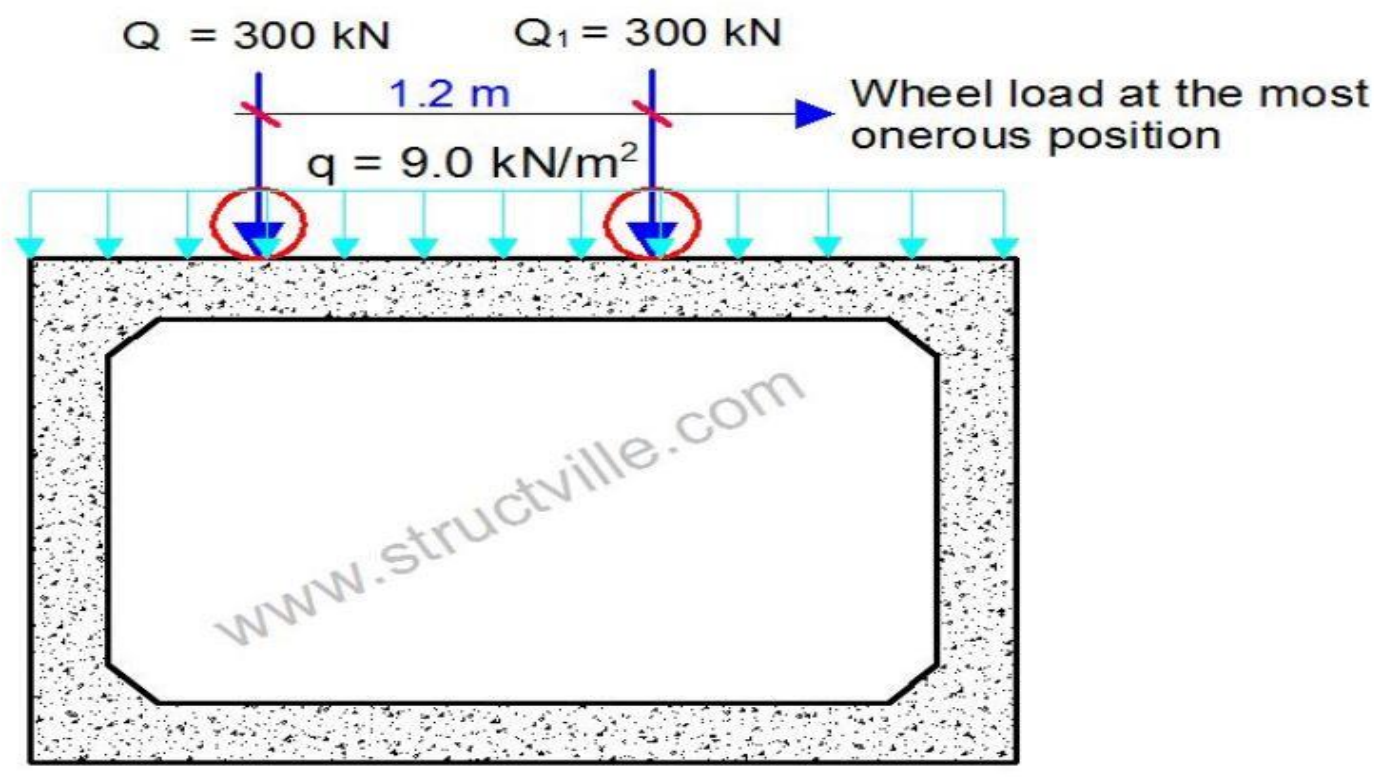

Fig 14: section of the culvert

\section{The Pern manne s.cuvens}

- Self-weight of the slap $=300 \mathrm{~mm}=0.3 \mathrm{~m}$

Self-weight of the slap per unit length $=0.3 \mathrm{~m} * 25 \mathrm{KN} / \mathrm{M}^{3}=7.5 \mathrm{KN} / \mathrm{M}^{2}$.

- Permanent action from asphalt layer

Thickness of the asphalt $=75 \mathrm{~mm}=0.075 \mathrm{~m}$.

Self-weight of the asphalt per unit length $=0.3 \mathrm{~m} * 25 \mathrm{KN} / \mathrm{M}^{3}=1.69 \mathrm{KN} / \mathrm{M}^{3}$.

For the purpose of this simplicity is to understand these parameters so, let's combine these two actions, gk= $7.5+1.69=9.19 \mathrm{KN} / \mathrm{M}^{2}$.

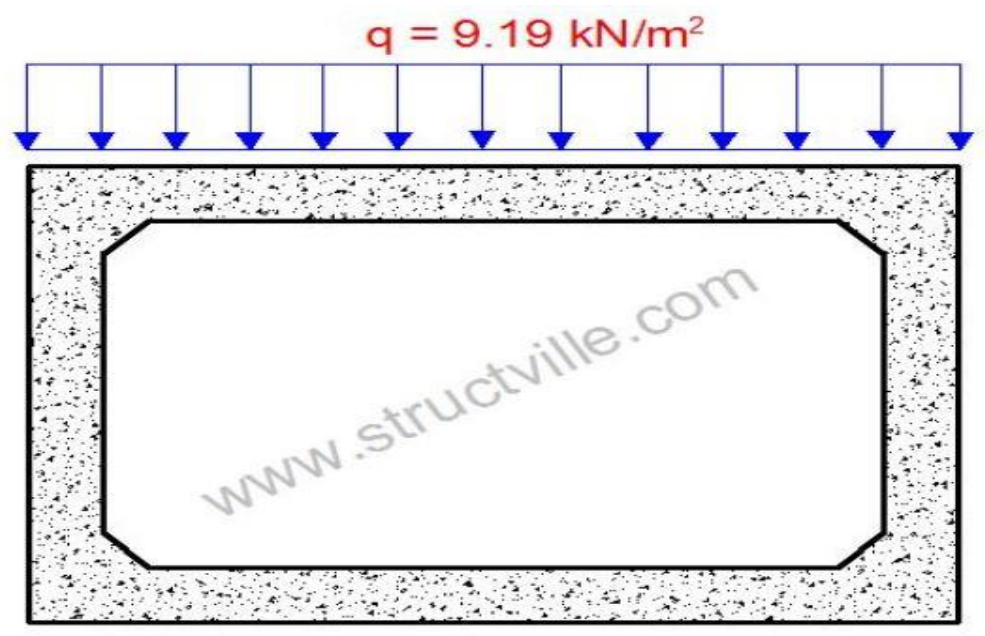

Fig 15: permanent actions of the top slap 


\section{- Earth Pressure}

The earthquake coefficient formula, $\mathrm{K}_{\mathrm{o}}=1-\sin (30)=0.5$.

The maximum earth pressure on the side walls

$\mathrm{P}=\mathrm{K}_{\mathrm{o}} \mathrm{pH}=0.5 * 19 \mathrm{KN} / \mathrm{M}^{3} * 2.3 \mathrm{~m}=21.85 \mathrm{KN} / \mathrm{M}^{2}$.

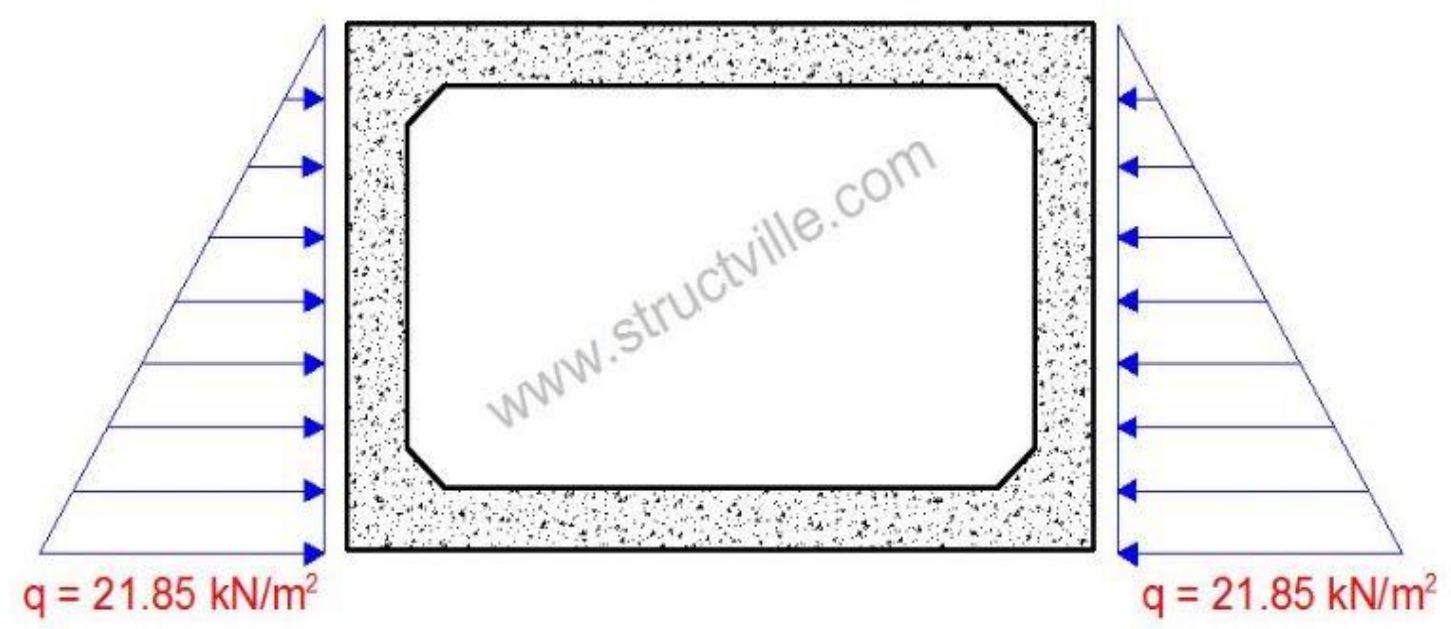

Fig 16:- Earth pressure

Live Load Surcharge

Live load surcharge is $\mathrm{q}=10 \mathrm{KN} / \mathrm{M}^{2}$.

Horizontal surcharge pressure $=\mathrm{Koq}_{\mathrm{O}}=0.5 * 10 \mathrm{KN} / \mathrm{M}^{2}=5 \mathrm{KN} / \mathrm{M}^{2}$.

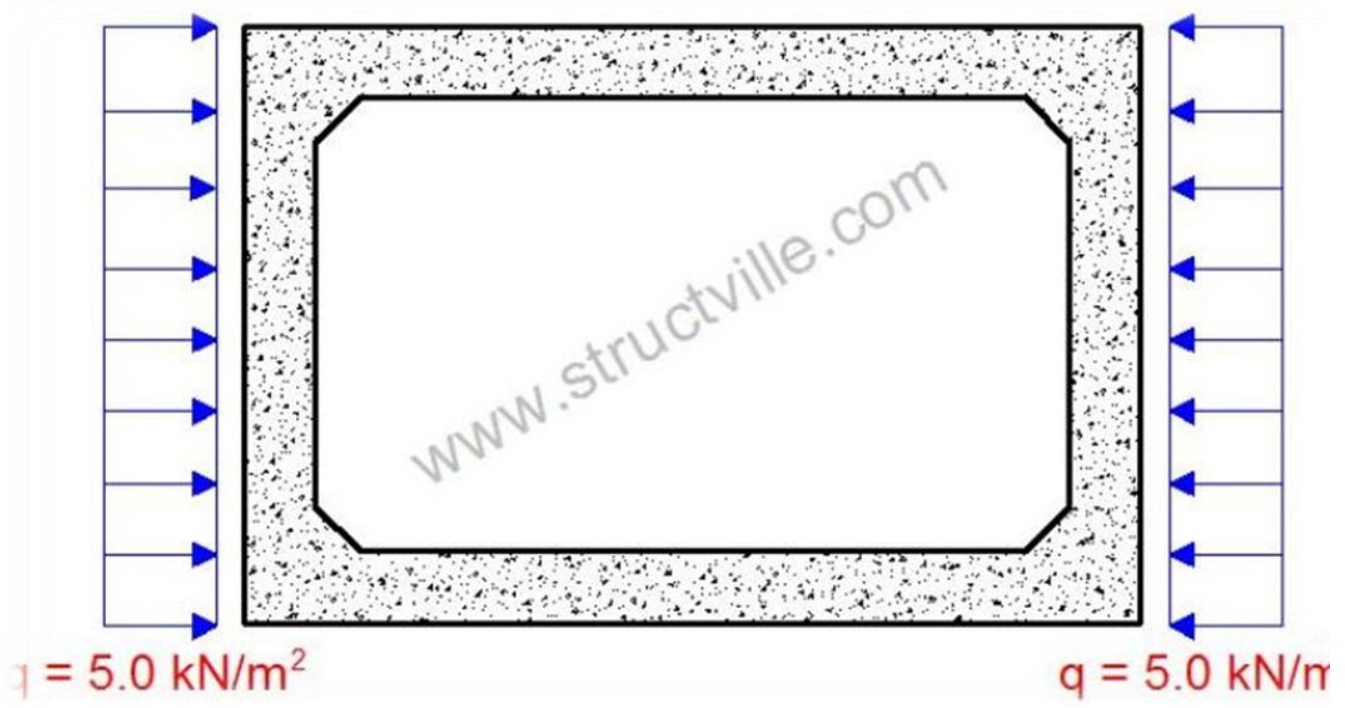

Fig 17: live load surcharge 


\section{- Box Culvert with $1.2 \mathrm{~m}$ thick earth fill}

Traffic loads that are acting on the box culvert, If the greater thickness of the fill is greater than $0.6 \mathrm{~m}$, we must consider the wheel loads of the traffic actions dispersed to the slap of the culvert as uniformly distributed load.

For this case, let us use load model 1 of EN 1991-2, which is recommended by clauses 4.9.1 of European code EN1991 - 2. the tandem loads can be considered to be dispersed through the earth fill and uniformly distributed on the top of the box culvert. The contact surface of the tires of LM1 IS $0.4 \mathrm{M} * 0.4 \mathrm{~m}$, which gives a contact pressure of about $0.9375 \mathrm{~N} / \mathrm{mm}^{2}$.

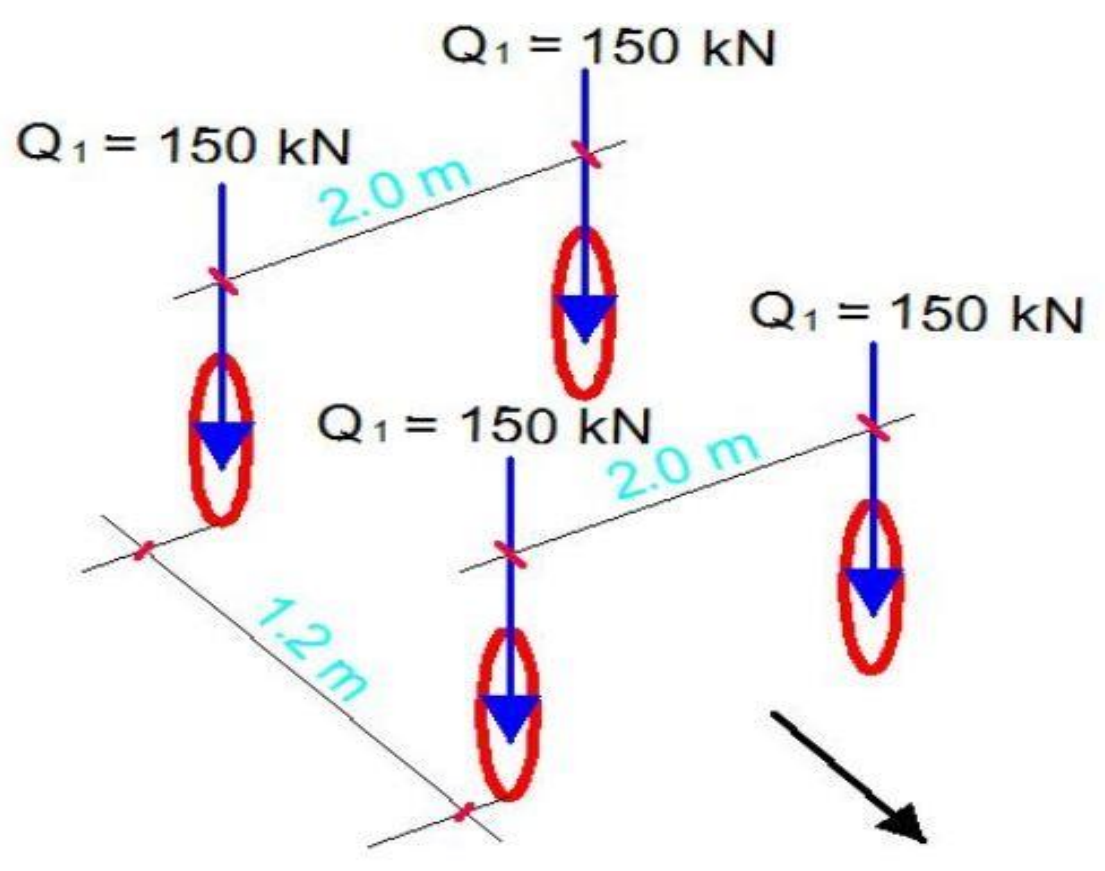

Fig 18: LM1 Tandem system

Then we are going to disperse the loads through the earthquake fill to the box culvert by using (vertical and horizontal) loads. Otherwise, we can use Boussinesq's method.

[EN 1991- 2- 2003, Eurocode] this code recommends a dispersal angle of 30o to the vertical for a wellcompacted earth fill. 


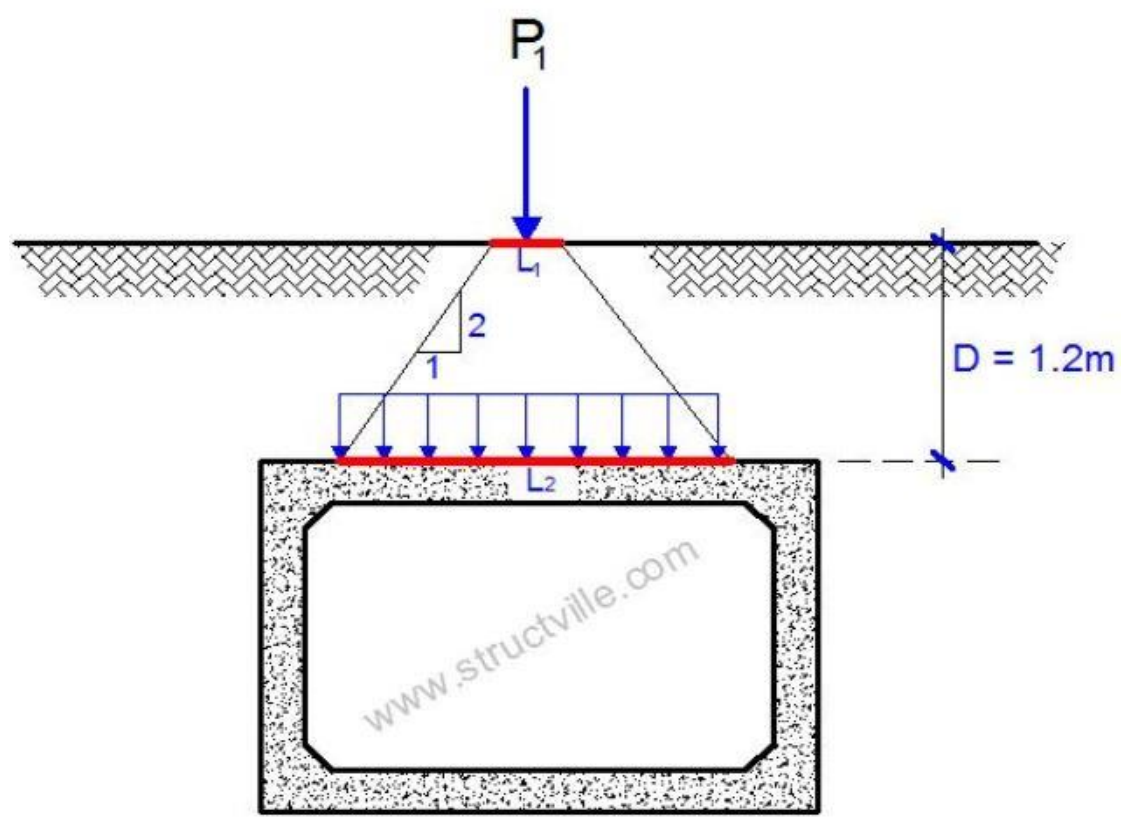

Fig 19: single wheel load distribution

For the arrangement of figure 9:

- $\mathrm{P} 1=150 \mathrm{KN}$

- $\mathrm{L} 1=0.4 \mathrm{M}$

- $\mathrm{L} 2=0.4+1.2=1.6 \mathrm{M}$.

Then the equivalent uniformly distributed load from each wheel to the box culvert is; $\mathbf{q}$ ec $=150 /(1.6 * 1.6)=58.593 \mathrm{KN} / \mathrm{M}^{2}$.

The wheel pressure in the axles can overlap when considering the tandem system, as shown in figure 10.

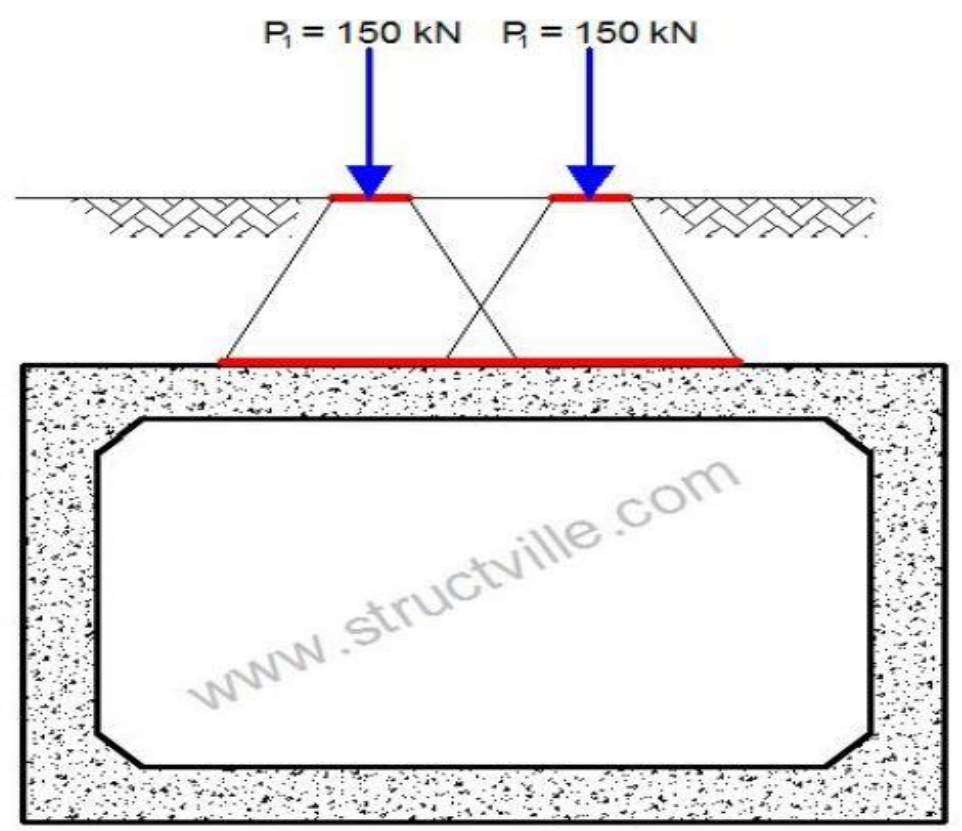

Fig 20: overlapping tandem axels load dispersion 
When considering the tandem system as like figure 10 shows;

$\sum P i=150+150+150=600 \mathrm{KN}$.

$\mathrm{L}_{2}=1.2+0.4+1.2=2.8 \mathrm{~m}$ (spacing wheel + contact length + depth of the fill)

$\mathrm{B}_{2}=2 \mathrm{~m}+0.4 \mathrm{~m}+1.2 \mathrm{~m}=3.6 \mathrm{~m}$ (spacing wheel + contact length + depth of the fill).

$\mathbf{q}_{\mathrm{ec}}=600 /(2.8 * 3.6)=59.523 \mathrm{KN} / \mathrm{M}^{2}$.

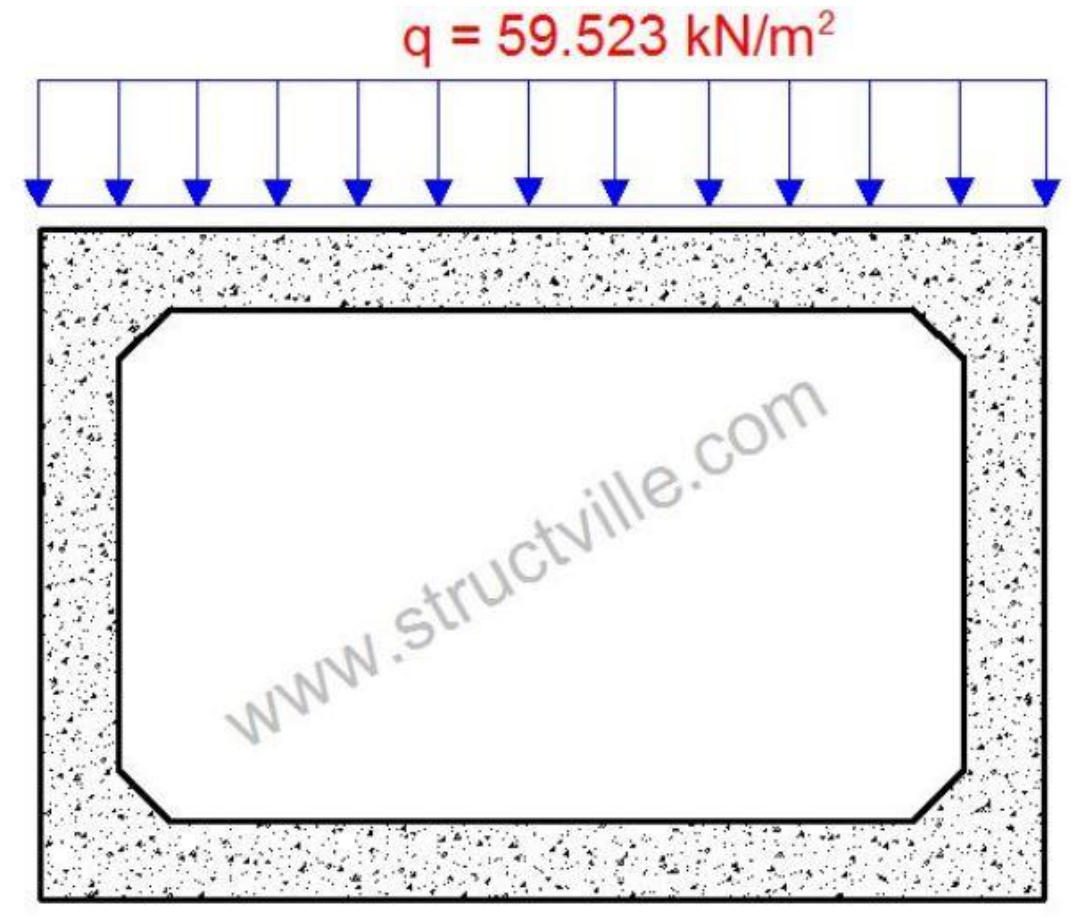

Fig 21: equivalent distribution loads on the top slap culvert

Earth Loads on the top of the box culvert

- At a depth of $1.2 \mathrm{~m}$, then the earth pressure on the box culvert is given by;

- $\mathrm{P}=1.2 * 19 \mathrm{KN} / \mathrm{M}^{3}=22.8 \mathrm{KN} / \mathrm{M}^{2}$

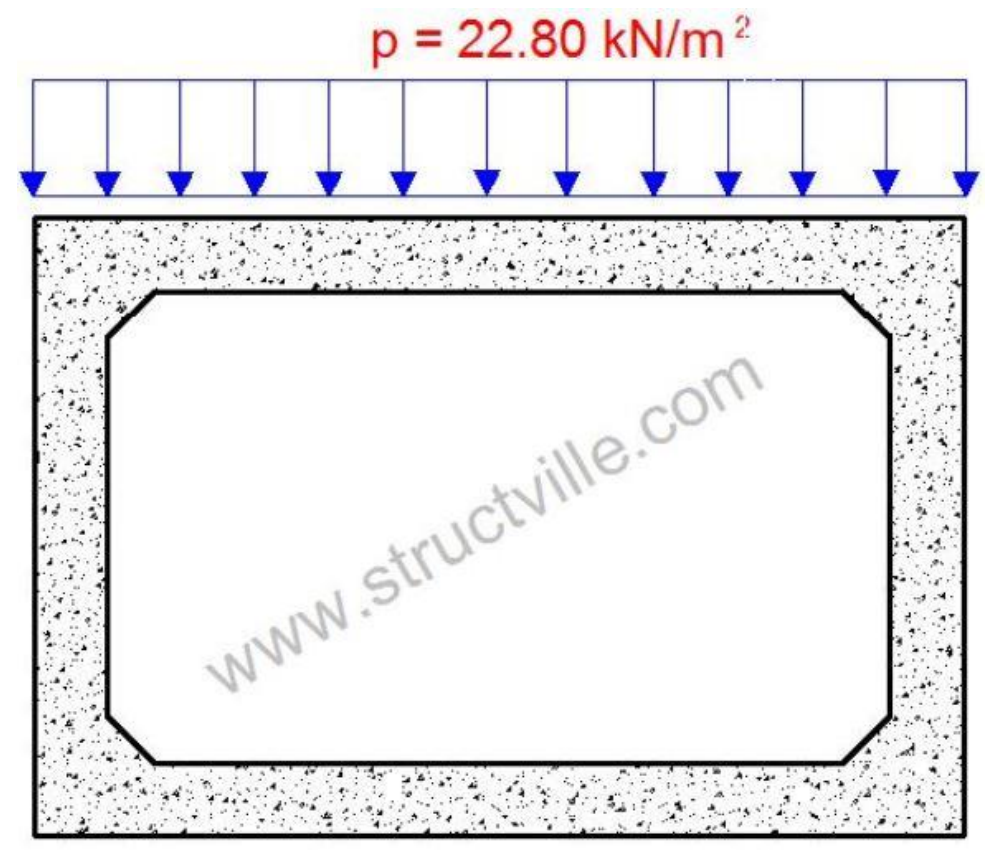

Fig 22: Earth load pressure 


\section{Horizontal pressure on the culvert}

Since the culvert is buried under the ground, the pressure is as given below.

The maximum pressure at the base of the culvert at $2.3 \mathrm{~m}$ is,

$\mathrm{P}_{\max }=\mathrm{koPH}=0.5 * 19 \mathrm{KN} / \mathrm{M}^{3} * 3.5 \mathrm{~m}=33.25 \mathrm{KN} / \mathrm{M}^{2}$.

The minimum pressure at the top of the culvert at $1.2 \mathrm{~m}$ below the ground is given by;

$\mathrm{P}_{\min }=\mathrm{koPH}=0.5 * 19 \mathrm{KN} / \mathrm{M}^{3} * 1.2 \mathrm{M}=11.40 \mathrm{KN} / \mathrm{M}^{2}$.

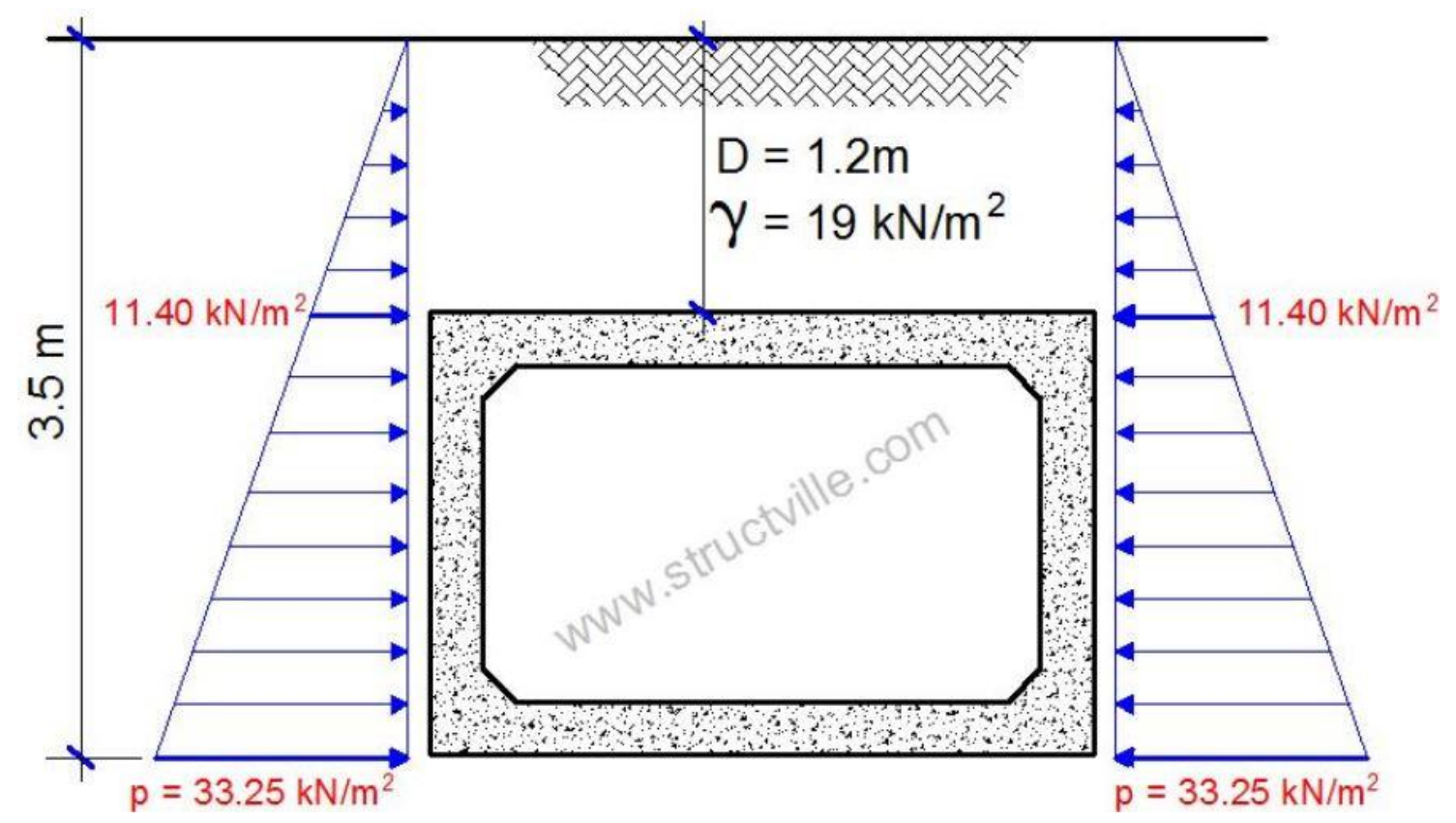

Fig 23: horizontal pressure on a buried box culvert

\section{Surcharge Loads}

The horizontal surcharge Load distribution on the buried box culvert will be the same as of case A.

\section{Moment and Shear Design of the Culvert}

The net bending moment and the net bending moment is calculated by Excel sheet 
Table 2: Moment Distribution Method

\begin{tabular}{|c|c|c|c|c|c|c|c|c|}
\hline Joint & \multicolumn{2}{|l|}{$\mathbf{A}$} & \multicolumn{2}{|l|}{ B } & \multicolumn{2}{|c|}{ D } & \multicolumn{2}{|l|}{$\mathbf{C}$} \\
\hline Member & $\mathrm{AC}$ & $\mathbf{A B}$ & $\mathbf{B A}$ & BD & DB & DC & CD & CA \\
\hline Length & 1.40 & 2.50 & 2.50 & 1.40 & 1.40 & 2.50 & 2.50 & 1.40 \\
\hline Moment of Inertia & 0.0250 & 0.0250 & 0.0250 & 0.0250 & 0.0250 & 0.0250 & 0.0250 & 0.0250 \\
\hline Disturb. Factor & 0.64 & 0.36 & 0.36 & 0.64 & 0.64 & 0.36 & 0.36 & 0.64 \\
\hline FEM & 3.10 & -41.67 & 41.67 & -3.10 & 3.72 & -52.02 & 52.02 & -3.72 \\
\hline Distribution & 24.72 & 13.84 & -13.84 & -24.72 & 30.96 & 17.34 & -17.34 & -30.96 \\
\hline Carry Over & -15.48 & -6.92 & 6.92 & 15.48 & -12.36 & -8.67 & 8.67 & 12.36 \\
\hline Distribution & 14.36 & 8.04 & -8.04 & -14.36 & 13.48 & 7.55 & -7.55 & -13.48 \\
\hline Carry Over & -6.74 & -4.02 & 4.02 & 6.74 & -7.18 & -3.77 & 3.77 & 7.18 \\
\hline Distribution & 6.90 & 3.86 & -3.86 & -6.90 & 7.02 & 3.93 & -3.93 & -7.02 \\
\hline Carry Over & -3.51 & -1.93 & 1.93 & 3.51 & -3.45 & -1.97 & 1.97 & 3.45 \\
\hline Distribution & 3.49 & 1.95 & -1.95 & -3.49 & 3.47 & 1.94 & -1.94 & -3.47 \\
\hline Carry Over & -1.74 & -0.98 & 0.98 & 1.74 & -1.74 & -0.97 & 0.97 & 1.74 \\
\hline Distribution & 1.74 & 0.97 & -0.97 & -1.74 & 1.74 & 0.98 & -0.98 & -1.74 \\
\hline Carry Over & -0.87 & -0.49 & 0.49 & 0.87 & -0.87 & -0.49 & 0.49 & 0.87 \\
\hline Distribution & 0.87 & 0.49 & -0.49 & -0.87 & 0.87 & 0.49 & -0.49 & -0.87 \\
\hline Carry Over & -0.43 & -0.24 & 0.24 & 0.43 & -0.44 & -0.24 & 0.24 & 0.44 \\
\hline Distribution & 0.43 & 0.24 & -0.24 & -0.43 & 0.44 & 0.24 & -0.24 & -0.44 \\
\hline Moment Sum & 26.84 & -26.84 & 26.84 & -26.84 & 35.67 & -35.67 & 35.67 & -35.67 \\
\hline
\end{tabular}




\section{Moment Diagram}

$M_{\max (+)}=36.66 \mathrm{KN} / \mathrm{M}$

$M_{\max (-)}=-26.84 \mathrm{KN} / \mathrm{M}, \quad$ Moment Design of the top slap = $36 \mathrm{KN} / \mathrm{M}$.

\section{Top Slab Moment Diagram}

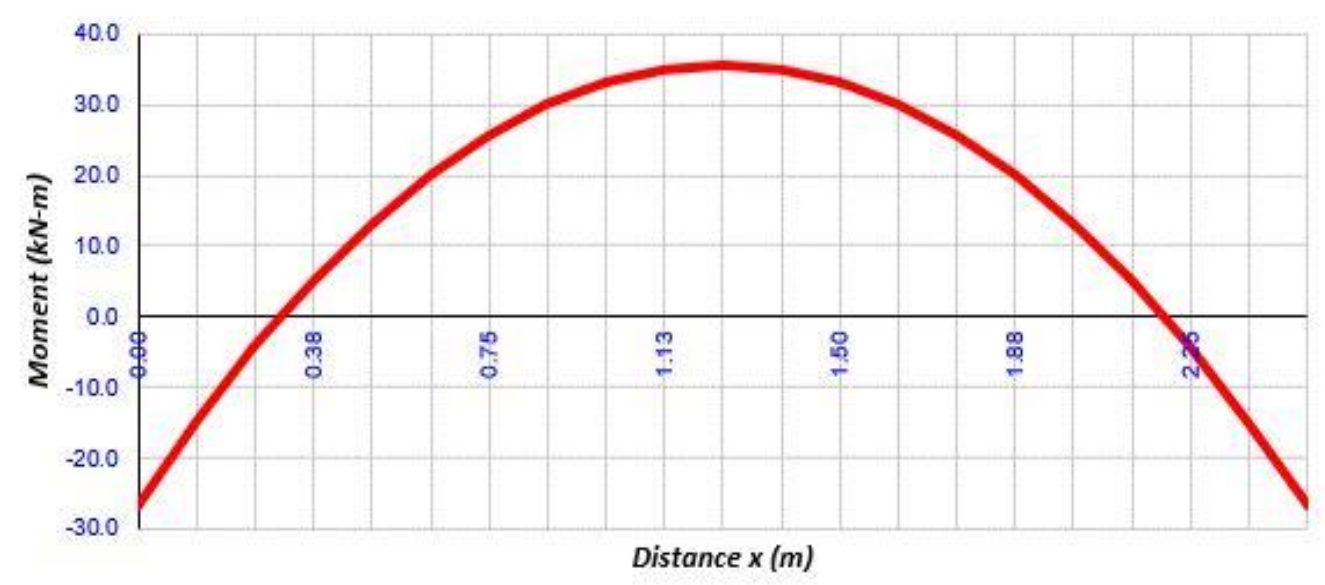

Fig 24: Moment Diagram

$\mathrm{V}_{\max (+)}=100 \mathrm{KN}$

$V_{\max (-)}=-90 \mathrm{KN}$, Shear Design of the top slap $=57 \mathrm{KN}$.

\section{Top Slab Moment Diagram}

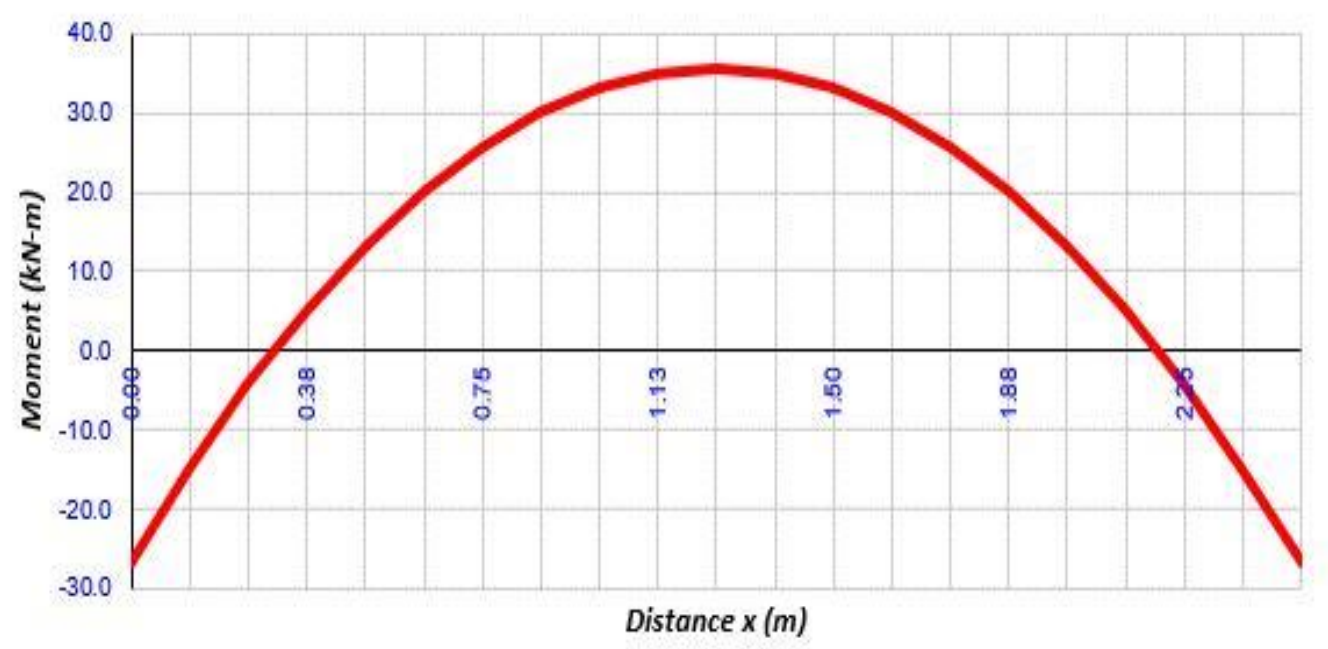

Fig 25: Shear Diagram 


\section{Bottom Slap Moment Diagram}

$M_{\max (+)}=36 \mathrm{KN} / \mathrm{M}$

$M_{\max (-)}=-42 \mathrm{KN} / \mathrm{M}, \quad$ Moment Design of the Bottom slap $=42 \mathrm{KN} / \mathrm{M}$.

\section{Bottom Slab Moment Diagram}

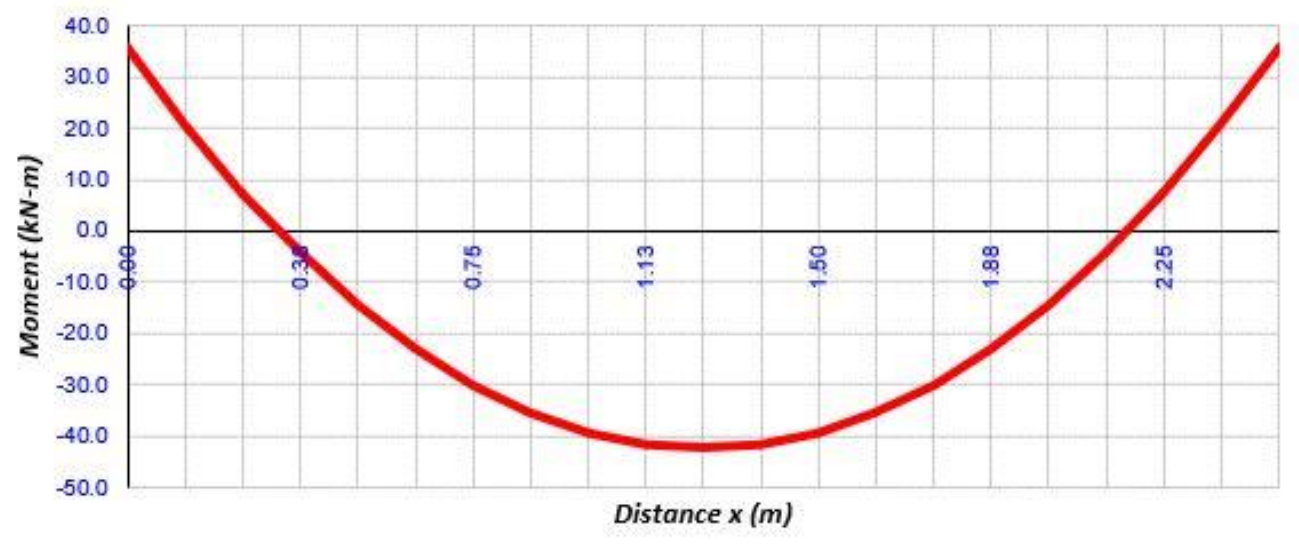

Fig 26:- Bottom slap moment diagram

$\mathrm{V}_{\max (+)}=125 \mathrm{KN}$

$V_{\max (-)}=-125 \mathrm{KN}$, Shear Design of the Bottom slap $=63 \mathrm{KN}$.

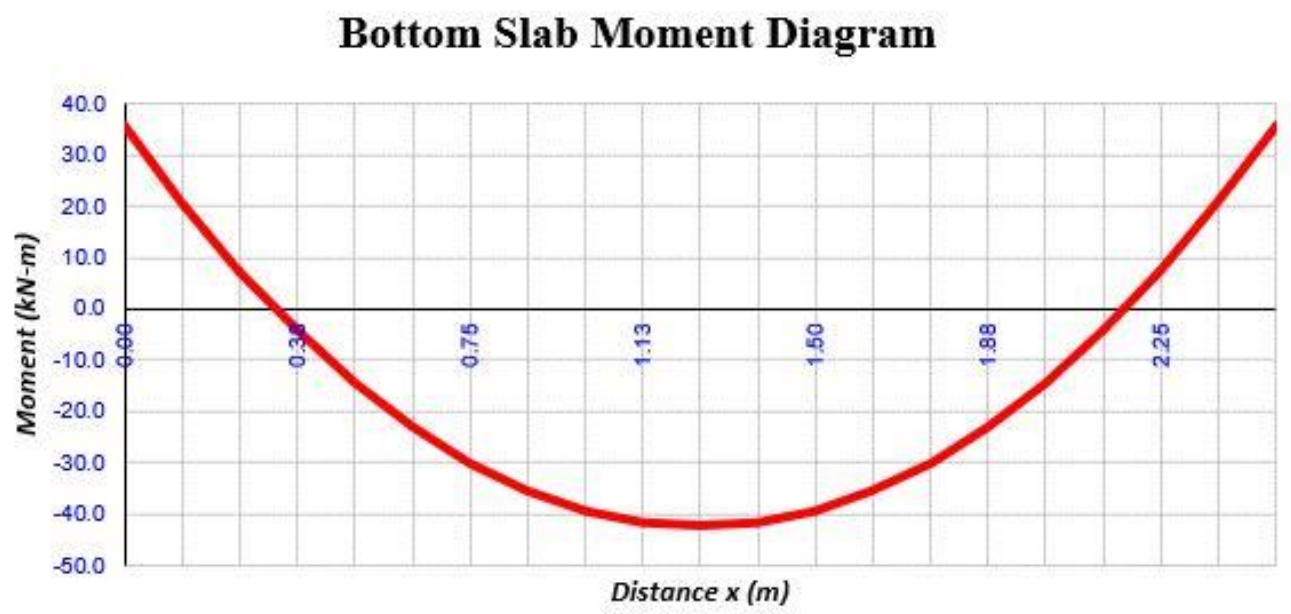

Fig 27: Bottom slap shear diagram 
Side Walls Moment Diagram

$M_{\max (+)}=36 \mathrm{KN} / \mathrm{M}$

$M_{\max (-)}=-23 \mathrm{KN} / \mathrm{M}, \quad$ Moment Design of the Side walls $=36 \mathrm{KN} / \mathrm{M}$.

\section{Side Walls Moment Diagram}

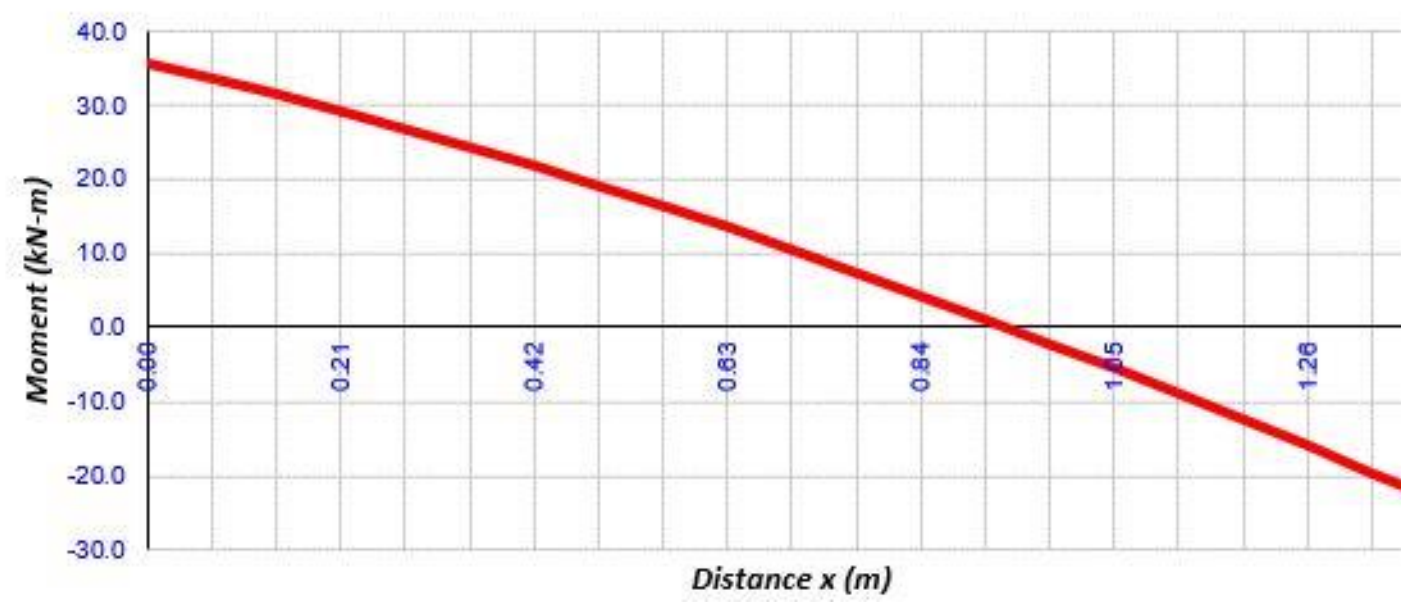

Fig 28: moment diagram of the side walls

$\mathrm{V}_{\max (+)}=-27 \mathrm{KN}$

$V_{\max (-)}=-49 \mathrm{KN}, \quad$ Shear Design of the side walls $=44 \mathrm{KN}$.

\section{Side Walls Shear Diagram}

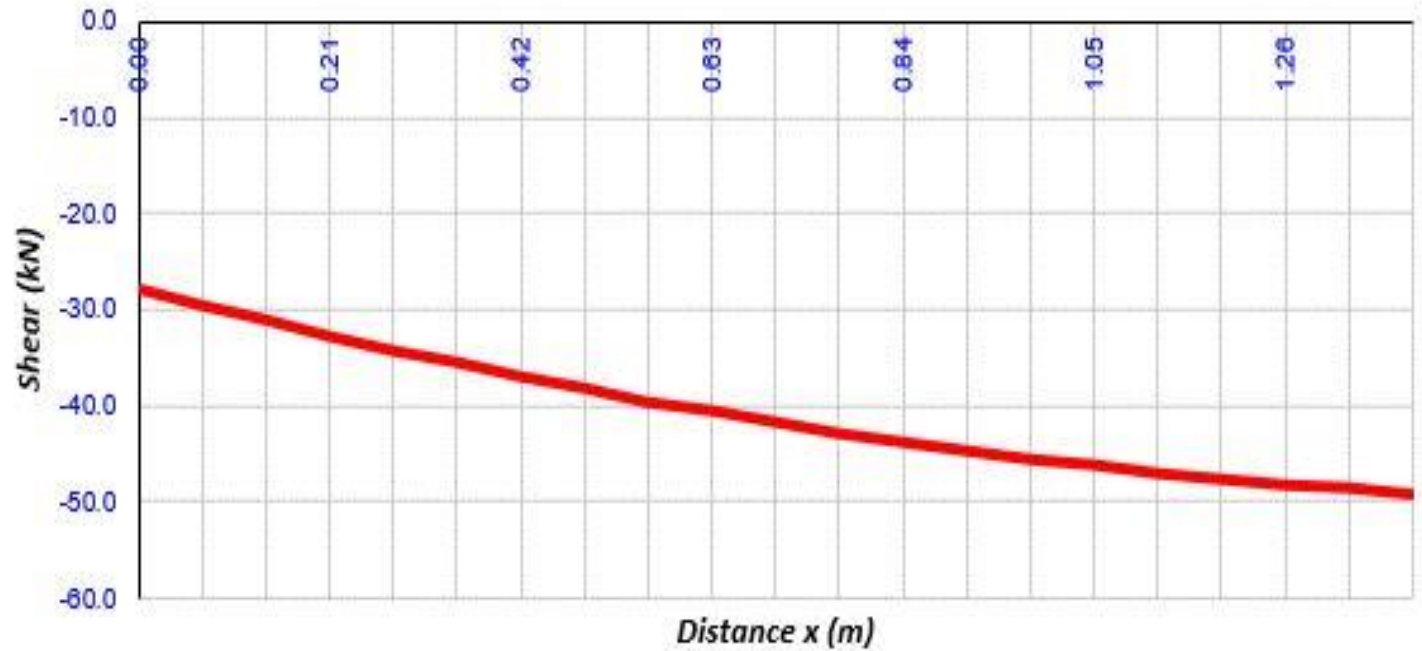

Fig 29: Shear diagram of the side walls 


\section{\# Reinforced Design Bars}

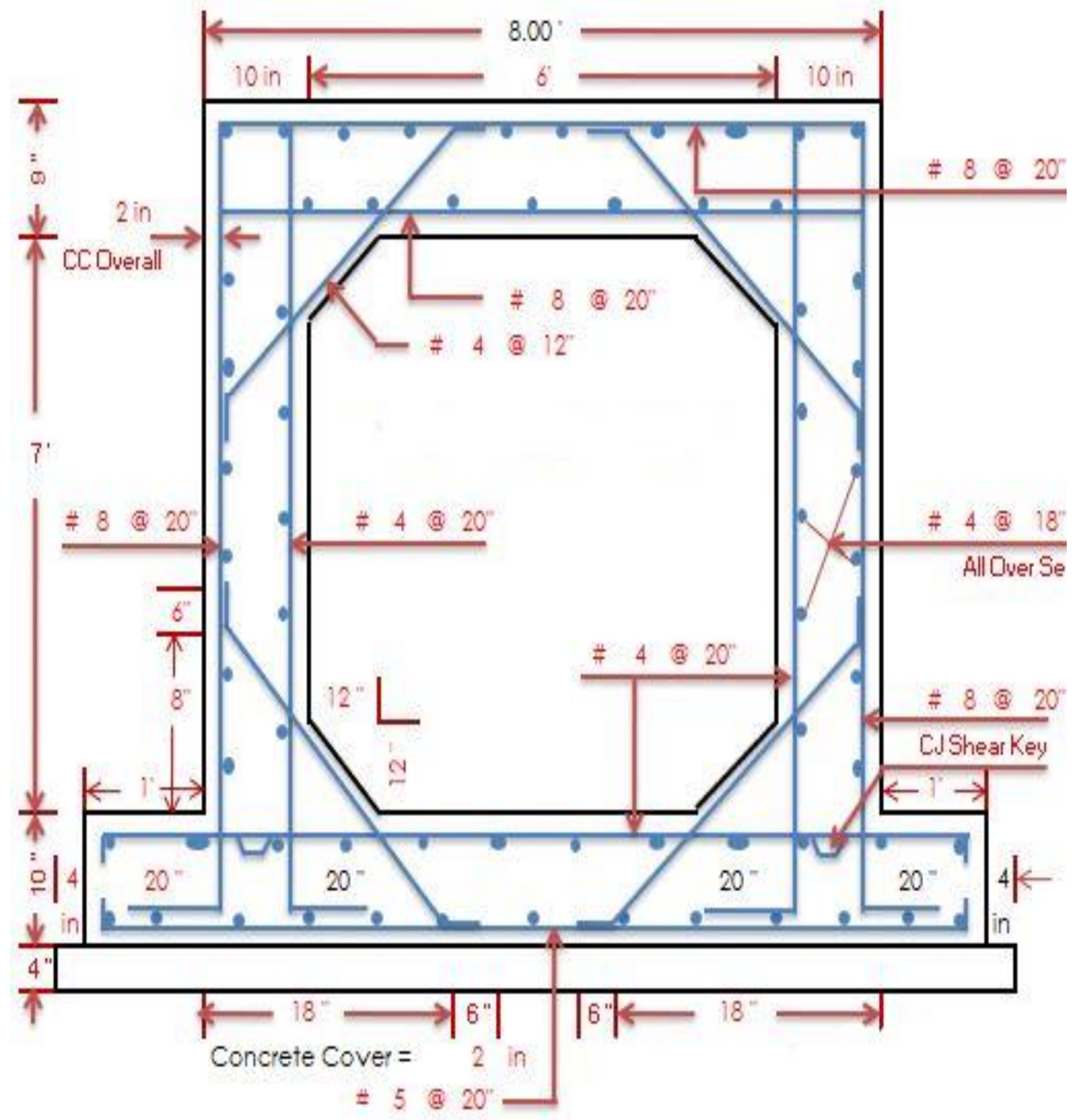

Fig 30: Reinforced Design 


\section{REFERENCES}

[1]. American Association of State Highway and Transportation Officials. Highway Drainage Guidelines. 1982.

[2]. Federal Highway Administration. Hydraulics of Bridge Waterways. Hydraulic Design Series No. 1. 1978.

[3]. Federal Highway Administration. Hydraulic Design of Highway Culverts. Hydraulic Design Series No. 5.

[4]. 1985

[5]. Federal Highway Administration. Debris-Control Structures. Hydraulic Engineering Circular No. 9. 1971.

[6]. Federal Highway Administration. HY8 Culvert Analysis Microcomputer Program Applications Guide.

[7]. Hydraulic.

[8]. U. S. Department of Interior. 1983. Design of Small Canal Structures. 